Discussion Paper Series A No.442

International Comparison in Historical Perspective:

Reconstructing the 1934-36 Benchmark Purchasing Power Parity for J apan, Korea and Taiwan

Kyoji Fukao

(The Institute of Economic Research, Hitotsubashi University), Debin $\mathrm{Ma}$

(Foundation for Advanced Studies on International Development (FASID), and University of Missouri at St. Louis)

and

Tangjun Yuan

(Graduate School of Economics, Hitotsubashi University),

September 2003

The Institute of Economic Research Hitotsubashi University Kunitachi, Tokyo, 186-8603 J apan 


\title{
International Comparison in Historical Perspective: Reconstructing the 1934-36 Benchmark Purchasing Power Parity for Japan, Korea and Taiwan
}

\author{
Kyoji Fukao, Debin Ma, Tangjun Yuan* \\ Corresponding Author: \\ Debin Ma \\ GRIPS/FASID Joint Graduate Program \\ 2-2 Wakamatsu-cho, Shinjuku-ku \\ Tokyo, 162-8677 Japan \\ Email: debinma@grips.ac.jp \\ Phone: 81-3-3341-0457
}

\begin{abstract}
:
This paper provides the first estimate of consumption purchasing power parity (PPP) converters for 193436 Japan, Korea and Taiwan by matching prices of more than 50 types of goods and services with consumption weights derived from household expenditure surveys. We find that the 1934-6 average consumer prices of Korea and Taiwan were about 0.86 and 0.84 times that of Japan respectively. Using our new benchmark estimate, we make a theoretical and empirical investigation on the possible sources of biases in existing estimates based on the exchange rate conversion and the 1990 backward projected method. Our estimate provides a vital link that allows us to conduct an overall review of structural change, ethnic income distribution and the historical trend of economic convergence or divergence for these three economies in the past century.
\end{abstract}

\footnotetext{
* Kyoji Fukao is professor of Economics at the Institute of Economic Research, Hitotsubashi University. Debin $\mathrm{Ma}$ is research fellow of the Foundation for Advanced Studies on International Development (FASID), Tokyo, Japan and Assistant Professor of Economics at University of Missouri at St. Louis. Tangjun Yuan is research fellow of the Graduate School of Economics at Hitotsubashi University. Research funding from "Comparative Quantitative Economic Analysis of Modern Asia" and "Long Term Economics Statistics on Asia: Industry, trade and economic growth," both projects funded by the Ministry of Education as well as funding from FASID are gratefully acknowledged. We would like to thank Toshiyuki Mizoguchi, Yasuhirou Terasaki, Konosuke Odaka, Osamu Saito, Tetushi Sonobe, Jean-Pascal Bassino and Myunsoo Cha for comments. Our paper also benefited from the participants of the research workshops of Comparative Economics Institute at Hosei University, the Institute of Economic Research at Hitotsubashi University and FASID. We alone are responsible for all errors.
} 


\title{
International Comparison in Historical Perspective: Reconstructing the 1934-36 Benchmark Purchasing Power Parity for Japan, Korea and Taiwan
}

\begin{abstract}
:
This paper provides the first estimate of consumption purchasing power parity (PPP) converters for 193436 Japan, Korea and Taiwan by matching prices of more than 50 types of goods and services with consumption weights derived from household expenditure surveys. We find that the 1934-6 average consumer prices of Korea and Taiwan were about 0.86 and 0.84 times that of Japan respectively. Using our new benchmark estimate, we make a theoretical and empirical investigation on the possible sources of biases in existing estimates based on the exchange rate conversion and the 1990 backward projected method. Our estimate provides a vital link that allows us to conduct an overall review of structural change, ethnic income distribution and the historical trend of economic convergence or divergence for these three economies in the past century.
\end{abstract}

The rejuvenation of growth theories and the rise of the "new" growth theories in the past decade have revolutionalized our intellectual thinking on issues of long-term economic development. Central to the empirical works of this burgeoning theoretical literature is the compilation of historical national accounts data in purchasing power parity (PPP) terms, exemplified by the masterly scholarship of the Penn World Table group and Angus Maddison.

While the debate on whether global economies are converging or diverging overtime is still ongoing, the miraculous rise of Japan, Korea and Taiwan from the aftermath of WWII has been undoubtedly a source of inspiration for the convergence school, as well as other aspiring developing economies. The past two decades have also seen a flourishing of scholarly works on the role of historical factors - particularly their shared colonial heritage in the pre-WWII period in the long-term economic development of these three economies. An important milestone in this literature is the systematic reconstruction of times series macroeconomic indicators of these three economies in the pre-WWII period using detailed statistics compiled by the Japanese government and its colonial administrations in Taiwan and Korea. This culminated in the publication of the statistical volume compiled by Mizoguchi and Umemura (hereafter referred to as $M \& U$ ) and published in 1988, which provided annual estimates of GDP and its various components for Taiwan and Korea in the colonial period. 
The GDP series of these three economies in the M\&U volume is based on the official one to one exchange rate, which shows the Taiwanese and Korean per capita GDP at about 60 and 40\% of the Japanese level in the 1930s. It has long been revealed by the purchasing power parity (PPP) doctrine that exchange rate conversion of international per capita income, which fails to incorporate relative price level differences in the non-tradable sector, tends to systematically underestimate the real per capita income level of the lower income countries (in this case Taiwan and Korea) (Balassa 1964, Samuelson, 1964, Bhagwati, 1984).

The GDP series in the M\&U volume also formed the basis of Angus Maddison's national accounts series. To arrive at globally comparable series, Maddison consistently used the 1990 benchmark PPP to project backward using domestic real GDP growth rates. Surprisingly, however, the Maddison backcast series based on the original M\&U data, gives the Taiwanese and Korean per capita GDP at $63 \%$ and $70 \%$ of the Japanese level around 1935 respectively, reversing the per-capita income ranking in the $\mathrm{M} \& \mathrm{U}$ volume.

As a resolution to this jarring discrepancy, this paper launches a full-fledged pre-War consumption PPP for Japan, Taiwan and Korea in 1934-36 through a three way bi-lateral matching of 50 to 60 types of goods and services, with three-level consumption expenditure weights derived from detailed household budget surveys. Our results show that the consumer prices of Taiwan and Korea are at about $84 \%$ and $86 \%$ of the level of Japan respectively. Under Japanese colonialism, all these three economies issued currencies denoted as yen, convertible within the empire at the 1:1 exchange rate. This alternatively meant that, in our case, one Japanese yen was equivalent to 0.84 Taiwanese yen and 0.86 Korean yen in consumer purchasing power.

This pre-war PPP estimate confirms the PPP doctrine that exchange rate conversion would under-estimate the real per-capita income of the relatively under-developed countries, Taiwan and Korea in our case. It also shows that the Maddison back-projected series, while under-estimating the per-capita income of Taiwan, exaggerated the pre-war Korean per-capita income. Clearly, 
there are serious index number issues embedded in the backward projection method that ignores long-term relative shifts in a country's terms of trade and economic structure. In the paper, we provide some preliminary empirical examination and theoretical expositions of the sources of the biases in these two types of estimates.

Our 1934-36 PPP benchmark provides a vital link through which we can examine issues of long-term growth trends for these three economies. In this paper, we supplement our statistical exercise with a historical and quantitative analysis of economic changes between the mid-1930s and 1990. We argue that in the pre-war period, while economic convergence had been taking place within these three economies under the highly-integrated Japanese colonial framework, it was fundamental breaks in political and economic regimes in the post-War era that witnessed major transformations in structures of production and trade, ethnic income distribution and most importantly, economic convergence towards the post-War global leading economies.

The rest of the paper is divided into two main sections followed by a conclusion. The first section provides a detailed explanation of our PPP estimation procedure and results. It then examines the extent of the bias inherent in pre-War exchange rate conversion and the 1990 benchmark backward projection method in the comparative context of the post-war International Comparison Project (ICP) studies. Section II focuses on the possible sources of these discrepancies in the historical context of Japanese colonialism in the pre-War era and the economic transformation of these three economies in the post-War era. The section ends with a summary that deals with the contrasting patterns of income distribution and economic convergence during these two benchmark periods.

\section{Benchmark PPP, Exchange Rate and the 1990 Backward Projection}

\section{The 1934-36 Consumption PPP}

We adopt the methodology used by several rounds of the ICP studies for the post-WWII benchmark periods and present a pre-War PPP for Japan, Taiwan and Korea in 1934-36 (For post-War ICP studies, see Heston and Summers 1993 and Maddison 1995). 
In our study, we make full use of the unusually rich and high-quality statistical data (by prewar standards) compiled by the Japanese government and its colonial administration that employed reasonably consistent standards, terminologies and methodologies for their statistical system within the empire. We also benefited from the wealth of information and worksheets accumulated under the Long Term Economics Statistics Project (LTES) initiated by Professor Kazushi Ohkawa at Hitotsubashi University, which produced long-term nominal and real GDP series for Japan and was later extended to colonial Taiwan and Korea by Mizoguchi and others. ${ }^{1}$ Retracing the steps they used to construct GDP and consumer price index provides us a shortcut to an otherwise extremely cumbersome PPP computation. Given the above, we believe our study differentiates from some other similar pioneering studies which had to compromise with the narrow set of commodity prices used and simplifying assumptions of consumption expenditure weights due to the data constraint for most non-industrialized countries in the pre-War period (Jan Luiten van Zanden 2002, Bassino and van der Eng 2002, Nakagawa 2000).

For our estimation, we collected absolute prices for items included in consumers' expenditure for major cities of different regions within these three countries. We treated each country's price as the simple average of the prices of these major cities. For Japan, the cities included are Tokyo, Osaka, Kyoto, Nagoya, Yokohama and Kobe. For Korea, they are Seoul, Mokpo, Taegu, Pusan, Pyongang, Shinuiju, Wonsan, and Chongjin. The Taiwan cities are Taipei, Keelong, Ilan, Hsinchu, Taichung, Changhua, Tainan, Chiai, Kaohsiung, Pingtung, Taitung, Hualiengan, and Makung. $^{2}$

\footnotetext{
${ }^{1}$ For Japan, there are the 14 volume series LTES publications in Japanese. For the English version, see the abridged one volume by Kazushi Ohkawa and Miyohei Shinohara.

${ }^{2}$ Since our PPP estimate is based on urban prices, we do not exclude the possibility that, considering the more agrarian and self-sufficient economies of Korea, urban-rural price differentials are likely to be larger than in the other two economies, thus possibly biasing downward our PPP adjusted real per-capita income for Korea. This problem is partly alleviated by our inclusion of 10 cities in Korea. The extent of the bias can only be ascertained when more rural price data become available.
} 
We then derive the consumption expenditure weights at three levels of aggregation (upper, medium and lower). Following Mizoguchi's choice of benchmark periods in his construction of the consumer price index, we select the three-year average of 1934-36 as our benchmark period because most Taiwanese and Korean household budget and rural surveys with consumption expenditure information are only available after 1930. More importantly, 1934-36 is also a period of relative economic and price stability, interposed between the severe deflation leading to Japan's banning of gold exports in 1931-32 and the late 1930s economic dislocation brought about by the outbreak of the Sino-Japanese War. Table 1 presents the aggregated five-item upper level rural and urban expenditure weights for these three countries.

\section{Insert Table 1}

To compute PPP, we use our database of absolute prices that matched altogether 61 types of goods and services for Japan-Korea, 58 for Japan-Taiwan and 41 for Taiwan-Korea. Our database also included the service sector such as utilities (domestic lighting and heating cost). Data on housing and medical expenses are difficult to obtain, thus we follow Mizoguchi (1971, 1975) and use residential construction cost (e.g. wage of construction workers, price of cement and so on) and annual salaries of doctors.

Using the matched prices and the detailed three level consumption weights, we carry out a standard PPP computation of a three way bi-lateral comparison of absolute prices with Japan serving as the numaire country. For $n$ numbers of goods and services, Japan's (sub- or superscripted as $J)$ price level relative to that of country $i,(i=$ Korea, Taiwan $)$ is calculated as follows:

$$
P_{i, J}^{J}=\frac{\sum p_{n}^{i} q_{n}^{J}}{\sum p_{n}^{J} q_{n}^{J}}=\frac{\sum \frac{p_{n}^{i}}{p_{n}^{J}} p_{n}^{J} q_{n}^{J}}{\sum p_{n}^{J} q_{n}^{J}}=\sum \frac{p_{n}^{i}}{p_{n}^{J}} \omega_{n}^{J}
$$


The formule using $i$ country's consumption weights is:

$$
P_{i, J}^{i}=\frac{\sum p_{n}^{i} q_{n}^{i}}{\sum p_{n}^{J} q_{n}^{i}}=\frac{\sum p_{n}^{i} q_{n}^{i}}{\sum \frac{p_{n}^{J}}{p_{n}^{i}} p_{n}^{i} q_{n}^{i}}=\frac{1}{\sum \frac{p_{n}^{J}}{p_{n}^{i}} \omega_{n}^{i}}
$$

Finally, the geometric average of the two price indices (the Fisher index) $P_{i, J}=\sqrt{P_{i, J}^{i} \times P_{i, J}^{J}}$ gives us $i$ country's absolute price level relative to that of Japan. ${ }^{3}$

The detailed price matching, consumption weights as well as data sources and methodologies are explained in Appendix A along with three data tables A-1, A-2 and A-3. Tables A-1 and A-2 show that the average consumer price levels of 1934-6, Korea and Taiwan are 0.86 and 0.84 times that of Japan respectively. Table A-3, which gives a direct bi-lateral price matching of Korea and Taiwan, shows the Korea price level at 1.03 times that of Taiwan, confirming the three-country transitivity conditions for relative price levels. The summary information of relative price levels is in Table 2.

\section{Insert Table 2}

\section{PPP vs. Exchange Rate}

GDP PPP includes the relative prices of investment and government consumption sectors, besides private consumption. However, for most developing countries, consumption PPP may serve as a reasonable proxy for GDP PPP due to the dominant share of private consumption in GDP, a result empirically corroborated by the ICP studies for developing countries in the postWar period (Kravis, 1984, p. 27). In the case of Taiwan and Korea in the pre-War period, their shares of private consumption in 1935 were 64 and 89 percent respectively (M\&U p. 234 and 236).

\footnotetext{
${ }^{3}$ The summation sign is summed across the $n$ types of goods and services. This will be true throughout the rest of the text.
} 
Furthermore, the active flow of goods, capital and people under the Japanese colonial framework tended to bring equalizing forces for prices across these three economies. Japanese capital and tradable investment goods such as machinery formed an essential part of capital formation in Taiwan and Korea for this period (Yamamoto 2000, chap. 6). Japanese personnel dominated the upper echelons of the colonial administrations in Taiwan and Korea. The wage rates of local construction workers and government employees were roughly comparable between Korea and Taiwan, both important segments of the government sector. ${ }^{4}$ All these suggest that relative price levels of the investment and government sectors in these three economies were more likely to be governed by the same forces that shaped the relative price levels in private consumption.

\section{Insert Table 3}

In view of the above, we present our benchmark consumption PPP adjusted per capita GDP of these three economies alongside the exchange rate converted estimates in Table 3. In comparison with the exchange rate conversion, Our PPP converter raised the Korean and Taiwanese per capita income in 1935 from 38 and 66 percent to 44 and 79 percent of the Japanese level respectively. Clearly, as we can see from Table 2, the much lower average price levels for the non-tradable sector in Korea and Taiwan relative to that of Japan, 0.71 and 0.78 respectively, is important in accounting for the downward exchange rate bias. This result, with Taiwan and Korea being regarded as under-developed relative to Japan for this period, corroborates the theoretical predictions of the productivity and factor proportion differential models.

Now we would like to compare our pre-war PPP with the post-war ICP studies. We denote $P L_{i}^{C}(t)$ as the ratio of country $i$ 's exchange rate converted per capita income over its GearyKhamis international price measured per capita income in year $t$ :

\footnotetext{
4 According to "Chosan Shotukufu Tokei Sho," (Statistics of Korea Governor General) and "Taiwan Shotukufu Nenpo" (Statistical Annals of Taiwan Governor General), "Nihon Teikoku Tokei Nenkan" (Statistical Annals of Japanese Empire), average annual salaries of ordinary government staffs were about 378, 409 and 532 yens respectively for Korea, Taiwan and Japan in 1934-36.
} 


$$
P L_{i}^{C}(t)=\xi^{i}(t) \frac{\sum p_{n}^{i}(t) e_{n}^{i}(t)}{\sum p_{n}^{G}(t) e_{n}^{i}(t)}
$$

where

$\xi_{i}(t)$ : nominal exchange rate of country $i$ 's currency to U.S $\$$ at time $t$.

$p_{n}^{i}(t)$ : country $i$ 's price of the $n$th good or service at time $t, n=1,2, \ldots N$;

$p_{n}^{G}(t)$ : the Geary-Khamis (GK) international price of the $n$th good or service of country $i$ in year $t$

$e_{n}^{i}(t)$ : country $i$ 's real per capita value-added of $n$th good or service at time $t$.

Following Hestons and Summers (1993), we define the ratio of country $i$ 's benchmark PPP over its exchange rate as country $i$ 's current price comparative price levels (with U.S being the benchmark country) by: $C P L_{i, U S}^{C}(t)=\frac{P L_{i}^{C}(t)}{P L_{U S}^{C}(t)} \cdot{ }^{5}$ Country $i$ 's PPP adjusted or GK price measured per capita income relative to that of the U.S at time $t$, can be written as $G D P R_{i, U S}=$ $\frac{\sum p_{n}^{G}(t) e_{n}^{i}(t)}{\sum p_{n}^{G}(t) e_{n}^{U S}(t)}$. Using a 34-country sample in the 1975 ICP benchmark study, we get the following regression result:

$$
\begin{aligned}
\log \left(C P L_{i, U S}^{C}\right)= & 0.06+0.43 * \log \left(G D P R_{i, U S}\right) \\
& (0.07) \quad(0.05) \quad\left(R^{2}=0.7\right)
\end{aligned}
$$

The numbers in parentheses are standard errors. The 34-country sample data is from Kravis, Heston and Summers (1982, p.12). The 1975 sample empirically confirms the positive correlation between a country's PPP adjusted relative real per capita income and its comparative price level, both measured with respect to that of the benchmark country.

\footnotetext{
${ }^{5}$ Since exchange rates in our mid-1930s benchmark studies are 1:1, the $P_{i, J}$ used in Table 2 is equivalent to $C P L_{i, J}^{C}$.
} 
To compare our 1934-36 pre-War PPP with the 1975 result, we use the Chow test to test the hypothesis of equality in the regression coefficient of the logarithm of per-capita GDP between the two sets of benchmark estimates. Note there are two differences between our pre-War PPP and the 1975 PPP: while our PPP is benchmarked on Japan, the 1975 PPP is based on the U.S; while our PPP uses the bilateral Fisher index, the 1975 PPP adopts the multilateral Geary Khamis international price approach. ${ }^{6}$ In order to take account of these differences, we assume that the constant term is different between the two sets of data. More specifically we estimate the following equation using pooled data of the 1975 34-country sample and our 1935 three-country sample,

$$
\log \left(C P L_{i, K}^{C}\right)=a+a^{\prime} * D U M+\left(b+b^{\prime} * D U M\right) * \log \left(G D P R_{i, K}\right)+u_{i, K}
$$

where $D U M$ denotes a dummy variable, which takes a value of one for our 1935 three-country samples. The subscript $K$ denotes the key country (either the US or Japan).

The statistics for the test of our null hypothesis of $b^{\prime}=0$ are $F(1,31)=0.78$ with $p$ value equal to 0.38 , which imply a non-rejection of the equal coefficients hypothesis at even the $30 \%$ significance level. In order to increase our pre-War PPP samples, we also use our 1934-36 coefficients to extrapolate backward to include additional four years: 1915, 1920, 1925 and 1930. And we conducted a similar Chow test using pooled data of the 1975 34-country sample and our 1915-35 three-country sample. Still, the resulting Chow test leads to non-rejection of the null hypothesis of equal coefficients between the two benchmark years at the $10 \%$ significance level $[F(1,39)=2.38, p=0.13]$. Thus, it seems that the statistical relationship between comparative

\footnotetext{
${ }^{6}$ It can be shown that from equation $\log \left(C P L_{i, U S}^{C}\right)=0.06+0.43 * \log \left(G D P R_{i, U S}\right)$, we can derive the Japan-based equation: $\log \left(C P L_{i, J}^{C}\right)=0.43 * \log \left(G D P R_{i, J}\right)+e_{i}-e_{j}$ where $e_{i}$ and $e_{j}$ stand for the error terms for $i$ country and Japan. Thus, the switch of benchmark countries will affect the constant and error terms but not the coefficients. Although the bilateral Fisher index differs from the multilateral international price approach in technicalities, they are conceptually similar in being both the current price and direct approach of PPP. More specifically, we assume, for our Japan based three country comparison, the ratio, $\sum p_{n}^{G}(t) e_{n}^{i}(t) / \sum p_{n}^{G}(t) e_{n}^{J}(t)$, is approximated by $\left[\sum p_{n}^{i}(t) e_{n}^{i}(t) / \sum p_{n}^{J}(t) e_{n}^{J}(t)\right] \div C P L_{i, J}^{C}$.
} 
price levels and per-capita income found in our pre-War benchmark PPP are in line with those in the post-War ICP results.

In contrast, the Chow test using the same 1975 34-country sample against Maddison's 1990 benchmark back-projected PPP estimates for these three countries for 1915, 1920, 1925, 1930 and 1935 reveals the opposite. The Chow test, with $F(1,39)=20$ and $p=0.0001$, unequivocally rejects the equal coefficients hypothesis. It shows that the relationship between comparative price levels and per capita income in Maddison's 1990 back-projected pre-War PPP for these three countries significantly differs from those in the Post-War ICP studies. We will discuss more rigorously the problem of Maddison's somewhat "anomalous" pre-War estimates and the potential biases of backward extrapolation in the next section.

\section{PPP vs. the 1990 Backward Projection}

As the original GDP data used in Maddison's 1990 backward projected real series largely came from the LTES series, Ohkawa and Shinohara (1979) for Japan and M\&U (1988) for Korea and Taiwan, here we can calculate Maddison's implicit GDP deflator, $P L_{i}^{E}(t, 90)$ for Korea and Taiwan as follows $(i=$ Korea, Taiwan):

$$
P L_{i}^{E}(t, 90)=\xi_{i} \sum p_{n}^{i}(t) e_{n}^{i}(t) \div \frac{\sum p_{n}^{i}(t) e_{n}^{i}(t)}{\sum p_{n}^{i}(t) e_{n}^{i}(90)} \sum p_{n}^{G}(90) e_{n}^{i}(90)
$$

where $\xi, p_{n}^{i}(t), e_{n}^{i}(t)$ are the same as defined earlier. The (90) is used to denote benchmark year 1990. We use the superscript $E$ for $P L_{i}^{E}$ to denote the extrapolated price level to distinguish from the current price level which used the superscript $C$.

Note that the numerator of $P L_{i}^{E}(t, 90)$ is just Korea or Taiwan's current price per capita GDP converted to U.S. \$ at the nominal exchange rate of time $t$. The denominator is Maddison's 1990 benchmark back projected Korea or Taiwan real per capita GDP at time $t$ expressed in GK dollars, 
which is the product of its 1990 GK benchmarked per capita GDP and its real GDP growth rates in their domestic national accounts between time $t$ and 1990.

With Japan being the benchmark country in our study, Korea and Taiwan's implicit GDP deflators relative to the Japanese price should be $C P L_{i, J}^{E}(t, 90)=P L_{i}^{E}(t, 90) / P L_{J}^{E}(t, 90) .^{7}$ Table 4 lists the original LTES's estimated 1911-1938 nominal series of per capita GDP in yen for the three countries (Ohkawa and Shinohara 1979 for Japan and M\&U 1988 for Taiwan and Korea) and the 1990 back projected real series. Columns 7 and 8 of Table 4 show the $C P L_{i, J}^{E}$ ratios. In striking contrast to our PPP study which gives both Korea and Taiwan price levels at about $85 \%$ of the Japanese level, the Maddison series shows a Korean price level (or GDP deflator) about half that of the Japanese level but that of Taiwan at similar or even higher levels than in Japan for the selected years of 1915-1935. The consequence of these contrasting comparative price levels on their respective per-capita GDP estimates are captured by Figure 1 which presents a confrontation of our estimates vs. Maddison's using the information in Table 2 and columns 9 and 10 of Table 4.

\section{Insert Table 4 and Figure 1}

Here, we again follow Heston and Summers (1993, p.363) and measure the deviation of the 1990 back projected PPP from current price benchmark PPP by using the ratio, $C P L_{i, J}^{C} \div C P L_{i, J}^{E}$. This ratio for Taiwan and Korea, according to Tables 2 and 4, is equal to $0.81(=0.84 / 1.04)$ and 1.59 (=0.86/0.54) respectively. In Figure 2, we plot our benchmark $C P L_{i, J}^{C} \div C P L_{i, J}^{E}$ ratios for Taiwan and Korea along with those for the four rounds of ICP studies covering 23 OECD countries in Heston and Summers (1993). In their case, the four largest European Union (EU) economies are the numeraire.

\footnotetext{
${ }^{7}$ With nominal exchanges for these three economies in the pre-War period always equal to $1: 1$, the $\xi_{i}$ and $\xi_{J}$ are equal and cancel out in the $C P L_{i, J}^{E}$ term.
} 


\section{Insert Figure 2}

Considering the difference in the choice of the benchmark country as well as the time span of backward projection, any direct comparison should be viewed as highly tentative. The plot, clearly show that while Maddison's under-estimation of Taiwan's ratio seems within the bounds for country samples in the four rounds of Post-War benchmark studies, the extent of overshooting in his Korea ratio is anomalously large.

The 1990 backward projected series that ranked the pre-War Korean per capita income higher than that of Taiwan, as will be shown later, runs counter to well-recognized historical studies and other related statistical findings. What are the plausible causes behind such a striking deviation? For this, a detailed decomposition of the CPL ratio may be illuminating. As we showed earlier, the Japan based CPL ratio can be written as:

$\frac{C P L_{i, J}^{C}(t)}{C P L_{i, J}^{E}(t, 90)}=\frac{P L_{i}^{C}(t) / P L_{J}^{C}(t)}{P L_{i}^{E}(t, 90) / P L_{J}^{E}(t, 90)}$. For ease of decomposition, we would like to focus on the $i$ country by using the ratio: $Z_{i}(t, 90)=P L_{i}^{C}(t) / P L_{i}^{E}(t, 90)$, written as follows:

$$
Z_{i}(t, 90)=\frac{\sum p_{n}^{i}(t) e_{n}^{i}(t)}{\sum p_{n}^{i}(t) e_{n}^{i}(90)} \sum p_{n}^{G}(90) e_{n}^{i}(90) \div \sum p_{n}^{G}(t) e_{n}^{i}(t) .
$$

The numerator of $Z_{i}(t, 90)$ is the Maddison style $t$ period's 1990 benchmark back projected per capita GDP and the denominator, $\sum p_{n}^{G}(t) e_{n}^{i}(t)$, is the direct $t$ year benchmark based per capita GDP estimate in GK price. Therefore, we can consider $Z_{i}(t, 90)$ as a measure of the extrapolation bias. For purposes of interpretation, we transform the $Z_{i}(t, 90)$ equation as follows:

$$
Z_{i}(t, 90)=\frac{\sum p_{n}^{G}(90) e_{n}^{i}(t)}{\sum p_{n}^{G}(t) e_{n}^{i}(t)} \times \frac{\sum p_{n}^{G}(90) e_{n}^{i}(90) / \sum p_{n}^{G}(90) e_{n}^{i}(t)}{\sum p_{n}^{i}(t) e_{n}^{i}(90) / \sum p_{n}^{i}(t) e_{n}^{i}(t)}
$$

Equation (1) decomposes the source of Maddison's deviation from the current price benchmark estimation into two components. The first item of the equation is country $i$ 's Laspeyres price index in GK international price between time $t$ and 1990 using its $t$ period 
quantity weight. For a relatively open and price-taking economy, this price index can be approximated by that country's Laspeyres terms of trade (export price index divided by its import price index) from $t$ to 1990 . Thus, an improvement (or deterioration) of country $i$ 's Laspeyres terms of trade between $t$ and 1990 could cause the 1990 back projected estimate to over-estimate (or under-estimate) country $i$ 's $t$ period per capita GDP relative to its $t$ period benchmark PPP estimate. In Appendix B, we present a theoretical derivation linking the terms of trade condition with the benchmark CPL ratio. Then using the ICP data shown in Figure 1, we conducted an econometric test and confirmed a statistically significant relationship outlined as above.

The second term of equation (1) is the ratio of a Paache quantity index (using the $1990 \mathrm{GK}$ price weight) over a Laspeyres quantity index (with the weight of the $t$ period domestic price). This ratio, which measures the discrepancy between real growth rates using the later period price weights and base period weights is broadly known as the Gerschenkron effect. This effect tends to be larger for economies experiencing greater structural and relative price changes during the studied period. Whether or not this effect over- or under-estimates a country's $t$ period per capita income depends on if there is a positive or negative correlation between the changes in the relatives prices and quantities of the corresponding sectors. ${ }^{8}$

In the case of our tri-partite comparison, which can be written as: $Z_{i}(t, 90) \div Z_{J}(t, 90)=$ $C P L_{i, J}^{C}(t) \div C P L_{i, J}^{E}(t, 90)$, we only need to re-interpret both the terms of trade and Gerschenkron effects in Korea and Taiwan relative to those of Japan. In the next section, we offer a historical and quantitative analysis of these three economies in the colonial period and their subsequent transformations in the post-War period to illuminate the causes of deviation using the 1930s exchange rates and Maddison's 1990 backward projection method.

\footnotetext{
${ }^{8}$ The Gerschenkron effect arises from the use of later and base price weights both of the same country. In our case, the later price weights are the Geary Khamis international price of 1990 . We are thus assuming the discrepancies in real growth rates using 1990 GK price and 1990 domestic price are relatively small, far smaller than using domestic later and base price weights. For a discussion of the Gerschenkron effect, see Edward Ames and John Calrson (1968).
} 


\section{Japanese Colonialism vs. East Asian Miracles}

\section{The Economics of Japanese Colonial Empire: a PPP perspective}

Japan's colonial acquisitions of Taiwan and Korea were the spoils of two military victories, the Sino-Japanese War of 1894-5 and the Russo-Japanese War of 1904-5. These victories also marked important turning points for Japan's evolving monetary integration with the global economy. The massive war indemnities that Japan managed to extract from the defeated Qing paved the way for her conversion to the gold standard in 1899. Through the victory of the 1905 Russo-Japanese War, Japan began a process of bringing these two formerly silver based Taiwan and Korea colonies into the gold exchange regime. By the 1910s, both colonial Korea and Taiwan were set on a de-facto "Japanese yen exchange standard," - the two colonial Central banks, the Bank of Korea and Bank of Taiwan, issued their bank notes as circulating currency convertible to the Bank of Japan notes which served as the de-facto reserve currency. All three bank notes were denoted as yen evaluated at the 1:1 exchange ratio within the empire. ${ }^{9}$

Concurrent with Japan's monetary integration was a process towards trade integration within the colonial empire. By the 1930s, the three economies under the colonial empire became closer to a free trade bloc protected by a common external tariff. ${ }^{10}$ The objective of the Japanese colonial economic policy had been to convert Korea and Taiwan into peripheries supplying agricultural commodities such as rice, sugar and industrial raw materials to the industrialized metropolis, Japan in exchange for her manufactured products.

Using detailed trade data from 1896 to 1940, Huang and Xu (1997) carefully documented this historical process of Taiwan being steadily but effectively absorbed into a developing and

\footnotetext{
${ }^{9}$ By the mid-1930s, a "yen currency block" came into formation with China's Manchuria falling under the Japanese colonial sphere (Yamamoto 2000, pp.84-93).

${ }^{10}$ Free trade was largely realized between Japan and Taiwan in the 1920s and 30s. But tariff rates and items to be taxed between Japan and Korea were reduced over several stages and only completely abolished in 1941 in order to ensure fiscal revenue for the cash-strapped Japanese colonial administration in Korea. See Yamamoto 2000, pp. 69-72.
} 
maturing Japanese colonial structure. Statistical tests based on the gravity model and other indices of trade composition such as intra-industry trade index and concentration ratios of largest exports items to total trade showed, firstly, Japan's steady but accelerating dominance in Taiwan's total external trade since 1896, accompanied by a corresponding retreat of other traditional trading partners such as mainland China and European powers. Secondly, while Taiwan's trade with mainland China and other countries as well as imports from Japan were relatively diversified in product variety, its exports to Japan were heavily concentrated on a narrow range of agricultural commodities, supporting the case of a colonial pattern of trade.

Such a structure of trade can be partly detected from our price database in Tables A-1 and A-2. For tradable goods, Taiwan and Korea's relative prices over that of Japan tended to be lower for basic food commodities (below 1) but higher (above 1) for manufactured products such as textiles and other processed food items like soy sauce and alcohol. In most cases, we can match the relatively lower priced tradable items with export goods and the relatively higher priced items with import goods in the colonial Korea and Taiwan trade statistics. ${ }^{11}$

Overall by 1935, Korea and Taiwan become highly trade-oriented with the external trade (imports plus exports) to GDP ratio reaching as high as 58 and 70 percent respectively, and with Japan taking more than 80 percent of their shares. ${ }^{12}$ This high level of economic integration would imply a substantial degree of price convergence among the three economies for the tradable sector, as confirmed by Korea and Taiwan's respective expenditure weighted relative price levels at as high as 93 and 84 percent of the Japanese level given in Table 1.

\footnotetext{
${ }^{11}$ For details on Korea and Taiwan's export and import goods, see Mizoguchi, 1975, p.40-1. It is worthwhile to note that the bilateral trade between Taiwan and Korea, in contrast to their bilateral trade with Japan, was only about 10 and 5 percent of their total external trade respectively. See Yamamoto 1989, p. 244.

${ }^{12}$ For trade data, see the trade matrix, see Yamamoto 1989, p.244. The GDE data is from M\&U, p.232 and p. 236. All are in current price of 1935.
} 
It also seems that, within this narrow range of price gaps, Taiwan emerged as having the lowest price level especially in food products. It has been recognized that colonial agricultural development was more successful in Taiwan than in Korea due possibly to the relatively favorable factor and natural resources endowments and possibly to the longer and more stable colonial rule. In contrast to Korea's trade deficit with Japan, Taiwan enjoyed a persistent trade surplus throughout most parts of the first three decades of the twentieth century.

However, a fuller explanation of Taiwan's relatively lower tradable prices has to incorporate an additional factor - Taiwan's relative geographic remoteness from Japan and Korea, which are located next to each other. Our preliminary research shows that freight rates of rice shipments from Osaka-Kobe to Taiwanese ports around 1940 were about 30 to 50 percent higher than they were to major Korean ports. ${ }^{13}$ This relatively higher shipping cost plus the longer travel time not only drives a wider wedge between import and export price but also creates a wider price band of import and export points inside which trade arbitrage would be contained. We tested the hypothesis of a wider price band between Taiwan and the other two countries using our price database and find that coefficients of variation over the relative prices of all tradable goods for Taiwan over Japan and Korea over Taiwan, equal to 0.33 and 0.35 respectively, does turn out to be higher than that of Korea over Japan, which is equal to 0.25 .

For non-tradable relative price levels, coefficients of variation reveal the opposite - Korea over Japan is higher than Taiwan over Japan. This result is consistent with the productivity and factor proportion differential models which predict that price levels of non-tradable goods are less sensitive to trade arbitrage but more responsive to local labor costs and domestic income.

In sum, this historical analysis serves to show that the relative price levels in these three economies reflects a host of inter-related factors such as factor endowments, geography, levels of economic development and economic integration under Japanese colonialism.

\section{From Colonial Empire to Economic Miracles: 1935 vs 1990}

From 1935 and 1990, these three economies saw a leap from the high stage of Japanese colonialism to the pinnacle of the East Asian miracle, having endured in between the vicissitudes

\footnotetext{
${ }^{13}$ Freight rates from Osaka, Kobe of Japan to Keelong and Kaosiung of Taiwan were 0.85 yen and 0.88 yen per tan respectively. For Pusan and In'chon, the freights were 1.4 yen and 1.66 yen per koku ( 1 koku $=2.5$ $\tan =150 \mathrm{kgs})($ Okazaki 1942, pp. 465 and 494). Note that the retail price used in our price database also included domestic retail margin and transportation cost, which are likely to be higher in Taiwan than in Korea given Taiwan's relatively higher non-tradable price level over that of Korea as shown in Table 1.
} 
of war devastation, hyperinflation, political turmoil and change of national boundaries in the case of Korea.

A common element underlying their economic miracles is their outward-orientation. Taiwan and South Korea in 1990, compared with 1935, had become even more trade-oriented - ratios of external trade to GDP reaching 76 and 80 percent respectively. ${ }^{14}$ But the change was far more structural than quantitative. In 1935, 90 and 76 percent of total exports from Taiwan and Korea respectively consisted of a narrow range of agricultural and primary products. In 1990 more than 90 percent of these two countries' exports were industrial products ranging from labor-intensive textile goods to high-tech and machinery products. For Japan, a similar but less drastic transformation occurred with primary and agricultural exports reduced from 13 in 1935 to less than 0.6 percent in 1990 (M\&U Tables 61 and 64, Yamazawa and Yamamoto Tables 3 and 4, Statistical Year Books of Japan).

Similarly by 1990, the geographic locations of trading for Taiwan and Korea greatly diversified in contrast to Japan's dominance in the colonial period. The United States emerged as the largest importer for all three economies, absorbing over 30 percent of their exports in 1990, while in 1935, this share for U.S was negligible, with the exception of Japan which saw the U.S taking about 17 percent of her goods (mostly textile products). Structural changes of such a magnitude in external trade were accompanied by similar transformational effects on their overall economic structure, particularly for Taiwan and Korea with high ratios of trade to GDP. Figure 3 captures this sharp contrast in economic structures as well as per capita incomes relative to that of the U.S between 1935 and 1990.

Insert Figure 3

\footnotetext{
${ }^{14}$ For Japan, this ratio actually declined from 27 percent in 1935 to 18 percent in 1990 largely because of the greatly expanded size of the Japanese economy by 1990. Data calculated from relevant issues of Statistical Year Books of these three economies.
} 
To account for how these structural changes affect the estimates of the back projected PPP, we would need detailed relative price data. Relevant issues of the statistical yearbooks of these three countries do seem to indicate that sectors that have grown the fastest, such as electronics and the machinery industry, tended to have the lowest price level increase relative to those of slowgrowing sectors such as agriculture during the period between 1960 and 1990, thus implying a substantial Gerschenkron effect in the backward projection method that tended to under-estimate per capita income estimates of countries with larger structural changes such as Taiwan and Korea. On the other hand, the 1935 benchmark based 1935-1990 Laspeyres price index, given the high share of agricultural sector, would be rising over time, to counter the above-mentioned Gerschenkron effect according to equation 1.

Given the data constraint as well as the scope of this paper, we are not yet to quantify the sources of the 1935 per capita income underestimation of Taiwan or the substantial overestimation of Korea caused by backward projection. Our quantitative and historical description, however, can confirm the serious index number problems from the 1990 back projection method caused by the significant long-term changes in relative prices and quantities in these three countries during the last five decades. ${ }^{15}$

\section{Income Distribution, Convergence or Divergence: from 1935 to 1990}

We now conduct a preliminary examination on the issue of economic growth and convergence between 1935 and 1990 based on our 1934-36 benchmark PPP estimate. Figure 4 shows that, despite the enormous economic transformation, the persistence of history does come through the ordinal ranking of the PPP per capita income for these three economies are identical between the benchmark years. Somewhat surprisingly, Taiwan's per capita income relative to Japan

\footnotetext{
${ }^{15}$ Using the information source cited in Maddison, 1995 for these three countries (p.146), we have reproduced per capita GDP series identical to what Maddison had in the book. It is interesting to note that South Korea per capita income was about equal to that of Taiwan in the late-1950s, indicating the statistical bias of the backward projection method may have already occurred in the post-War period and then amplified when linking with the pre-War period especially in the case of Korea which saw a split of national territories.
} 
actually declined from 79 percent in 1935 to 55 percent in 1990. Per capita income in South Korea did catch up slightly with that of Japan, rising from 44 percent in 1935 to 48 percent in $1990 .^{16}$

The observation of a lack of income convergence or even divergence in the case between Taiwan and Japan during this period is however misguided. Firstly, the seemingly narrow per capita income differences among these three economies may have been the achievement of their high degree of economic integration as well as the disguise for a colonial ethnic income distribution problem, both the end product of colonialism. In comparison with the presence of Westerners in their Asian colonies, the number of Japanese residents living in Korea and Taiwan in the 1930s was far higher. ${ }^{17}$ Japanese residents in Taiwan and Korea enjoyed much higher average per-capita income partly due to their disproportionate over-representation in skilled and management occupations. But even controlling for occupation, persistent gaps in per capita incomes still looms large between the Japanese residents and the native population.

This point is supported by information culled from the urban household budget survey in Taiwan, used in our PPP study for expenditure weights. The table shows that controlling for occupation, urban per capita household income of Taiwanese residents was only $52 \%$ of that of the Japanese residents in Taiwan. In fact, the per capita income and expenditure of Japanese residents living in Taiwan, if adjusting for PPP, would be roughly $40 \%$ higher than their compatriots of the same occupation living in Japan in 1937.

\section{Insert Table 5}

A tentative estimate by Mitsuhiko Kimura shows that, with the shares of Japanese residents in the total population of Taiwan and Korea equal to 5.1 and 2.7 percent respectively around the

\footnotetext{
${ }^{16}$ Considering that the colonial Korea included the then relatively more developed Northern part, South Korea's catch up with Japan from 1935 to 1990 would be larger if we incorporate the territorial change.

${ }^{17}$ For comparative studies of Western and Japanese residents living in their colonial territories, see Maddison, 1990, p.363.
} 
mid-1930s, their income shares (the averages of 1930 and 1940) in total Taiwan and Korea's national income are 26 and 22 percent respectively (Kimura 1998, pp.30-1). ${ }^{18}$ This would give per capita GDP of native Taiwanese and Koreans (excluding the Japanese residents) at 75 and 78 per cent of the average national per capita GDP (including the Japanese residents). Thus, the native Taiwanese and Korea per capita income (excluding the Japanese residents), in PPP terms, are now 59 and 34 percent of the per capita income of Japan in 1935, lower than the 79 and 44 percentage figures which included the per-capita income of the Japanese residents. This new result shows that, taking into consideration the ethnic income distribution, while Taiwan's relative per capita income gap with Japan in 1935 remained about the same as in 1990, South Korea made a fairly substantial catch-up.

But a more important lesson in this comparison is obscured by our use of Japan as the yardstick. The East Asian miracle is not characterized by their catch-up with each other but their convergence towards the global leading economies. A U.S based comparison would show that the Japanese per capita income surged from 37 percent in 1935 to 85 percent of the U.S level in 1990, while for Taiwan and Korea, these ratios rose from 30 and 16 percent to 47 and 41 percent respectively during this period. Taking account of the ethnic income distribution would imply that the income of the population of Taiwan and Korea had actually started only at 22 and 13 percent respectively, of the U.S level in 1935.

This carries real economic implication beyond a mere statistical switch of comparison base. Despite the high degree of integration achieved under the Japanese colonial framework, economic gains from the division of labor and specialization were limited both by the size of the empire as well as Japan's own relatively under-developed economic state (compared with the global economic leaders of the time). Thus, colonial income convergence within the empire achieved through empire-wide economic integration co-existed with a substantial gap with the world's

\footnotetext{
${ }^{18}$ Population share figures from M\&U, Table 23 on p. 256.
} 
leading economies of the time. But by 1990 , freed from the colonial restrictions, all these three independent economies were able to fully exploit their comparative advantages under a greatly expanded global market. The integration of these three economies in the Post-War period was more global than regional. With the collapse of the colonial structure that had once pulled them closer to each other, these three economies gravitated towards the world leading economies in the post-War era.

\section{Conclusion}

Our study provides a set of pre-War benchmark conversion standards for comparison of income, consumption as well as other monetary indicators of these three economies in the preWWII period for Japan, Taiwan and Korea, a standard that is superior to both the exchange rate conversion and backward projection, each dogged by its inherent biases.

Our pre-War consumption PPP confirms that the exchange rate conversion consistently underestimated Taiwan and Korea's per capita income relative to that of Japan as predicted by the factor proportion and productivity differential models. Furthermore, our PPP result reveals the substantial exaggeration of Korea's pre-War per capita GDP given by the 1990 backward projection method.

Although this paper demonstrates that biases arising from pre-War exchange rates seem far less severe and more predicable than those from backward projection, we do not advocate a general stance that, in the absence of current price PPP, exchange rates should be favored over backward projection. Rather, we advocate a case for careful historical and country-specific analysis. We believe the relative merits of exchange rates vs. backward projection rest on the historical nature of these three economies, with biases from pre-war exchange rates minimized by high economic integration under Japanese colonialism, but biases from backward projection magnified by the historically unprecedented economic transformation in the Post-War era. 
Our pre-War PPP benchmark provides a solid footing on which the long-term issues of economic convergence or divergence in these three countries can be analyzed. Although our paper confirms other studies on the colonial origin of economic catch-up and convergence of Korea and Taiwan in the post-War period, we also emphasize a fundamental break and a process of "de-colonization" between the pre- and post-War period in the post-War evolution of income distribution, economic and trade structure.

Modern economic growth in East Asia originated in the mid- $19^{\text {th }}$ century Meiji Restoration in Japan as a powerful pro-active response to encroaching Western colonialism. Ironically, it was precisely the success and avidness of this "Western learning" by Meiji Japan that spawned the Japanese colonialism soon to impinge on Taiwan and Korea, two former peripheral territories of a Confucius dominated East Asia. The strengthening of private property rights, the building of modern physical infrastructure, the diffusion of mass literacy - all reform programs that not too long ago passed the Meiji experiment in Japan - turned out to be an effective recipe for economic growth in the early $20^{\text {th }}$ century Taiwan and Korea despite the various colonial economic distortions. The colonial heritage in the form of social-infrastructure - human capital, entrepreneurial knowledge and more importantly, the ideology of a developmental state - proved to be far more enduring and important in explaining the post-War economic miracle of Taiwan and Korea.

Through this study, we hope to lay the foundation of a framework, which not only insists on a historical view where post-War economic growth should be tied with pre-War economic conditions, but also an integrated East Asian framework under which neither the one and a half century of modern economic growth in Japan, nor the post-War economic miracles of Taiwan and Korea should be studied independently from each other. For this to occur, constructing pre-War PPP is a first necessary step.

\section{References}


Ames, Edward and Carlson, John A. (1968) "Production Index Bias as a Measure of Economic Development" Oxford Economic Papers, Vol. 20, Issue 1 (March, 1968), 24-37.

Bhagwati, Jadish N. (1984), "Why Are Services Cheaper in Poor Countries?” Economic Journal 94 (June 1984): 279-285.

Balassa, Bela (1964) “The Purchasing Power Parity Doctrine: A Reappraisal,” Journal of Political Economy, vol. 72: pp. 584-596.

Bassino, Jean-Pascal, and Pierre van der Eng (2002) "Economic Divergence in East Asia: New Benchmark Estimates of Levels of Wages and GDP, 1913-1970."Paper presented at the XIII Economic History Congress held in Buenos Aires 22-26 July 2002.

De la Escosura, Leandro Prados (2000) "International Comparisons of Real Product, 1820-1990: Alternative Data Set" Explorations in Economic History. Vol. 37, No.1, Jan. 2000.

Directorate-General of Budget, Accounting \& Statistics Executive Yuan, Statistical Yearbook of the Republic of China, Various Years

Heston, Alan and Robert Summers (1993) "What Can be Learned from Successive ICP Benchmark Estimates?” Explaining Economic Growth, edited by Szirmai, A., Van Ark, B and Pilat, D. Elsevier Science Publishers.

Huang, D.X. and Xu, M.X (1997), "Zimin Guanxi yu Moayi Xinta Za Taiwan Rechuxiqi de Yanzhen" (A Test on the Colonial Trading Relations in Taiwan's Colonial Period) Taiwan Economic Review, 25:3 (1007), 369-399.

Kimura, Mitsuhiko (1998) "Chosan, Taiwan ni Okeiru Minzoku Kan Shotuku Bunpai, 1930-40 Nen" (Ethnic Income Distribution in Korea and Taiwan, 1930-40) Kokumin Keizai Zashi, Vol. 175, No. 2, pp. 29-37.

The Korea Statistical Association, Korea Statistical Yearbook, Various Issues.

Kravis, Irving B., Heston, A. and Summers, Robert (1982), World Product and Income, International Comparisons of Real Gross Product. Baltimore: Johns Hopkins University Press.

Kravis, Irving B., (1984) "Comparative Studies of National Incomes and Prices" Journal of Economic Literature Vol. XXII (March 1984), pp. 1-39.

Maddison, Angus (1990), "The Colonial Burden: A Comparative Perspective" in Maurice Scott and Depak Lal, eds., Public Policy and Economic Development: Essays in Honour of Ian Little. Oxford: Clarendon Press.

(1995) Monitoring the World Economy 1820-1992, OECD, Paris, France

Mizoguchi, T (1971) "Kakou Keiretu 9" (Worksheet No. 9), Institute of Economic Research, Hitotsubashi University. 
(1975) Taiwan · Chousen no Keizai Seichou---Bukka Toukei wo Chuushin to shite (Economic Growth of Taiwan and Korea: a Study of Prices). Tokyo: Iwanami Shoten.

Mizoguchi, T. and Umemura, Mataji (eds.) (1988), Basic Economic Statistics of Former Japanese Colonies 1895-1938. Tokyo: Toyo Keizai Shinpousha.

Mizoguchi, T. and Nojima, Noriyuki (1996) "Taiwan, Kankoku no Kokumin Keizai Keisan Chouki Keiretsu no Suikei" (Estimation of the Long Term National Accounts of Taiwan and Korea) Asian Historical Economic Statistics Project Discussion Paper: R96-6, Tokyo: Institute of Economic Research, Hitotsubashi University.

Nakagawa, Hironobu (2000) "Estimating Purchasing Power Parity Converters for International Comparisons Across Asian Countries: Prewar Case." Discussion Paper No.D99-18, The Institute of Economic Research, Hitotsubashi University.

Ohkawa, Kiyoshi, and Shinohara Miyohei (1979) Patterns of Japanese Development: A Quantitative Appraisal, Yale University Press, New Haven, CT.

Okazaki, Yukihisa (1941), Kaiun (Marine Transportation). Osaka: Diamond Publishing.

Ono, Fumihide (1927) Shouhin Tan-i to Nizukuri (Units and Weights of Commodities), Tokyo: Toyo Keizai Shinpousha.

Pilat, Dirk, (1994) The Economics of Rapid Growth, the Experience of Japan and Korea. Edward Elgar Publishing Co.

Samuelson, Paul (1964) "Theoretical Notes on Trade Problems," Review of Economics and Statistics, vol. 46: pp. 145-154.

Statistics Bureau, Management and Coordination Agency, Japan Statistical Yearbook, Various Issues.

Summers, Robert, and Alan Heston (1991) "The Penn World Table (Mark 5): An Expanded Set of International Comparisons, 1950-88.”Quarterly Journal of Economics, May 1991.

Van Zanden, Jan Luiten (2003) "Rich and Poor Before the Industrial Revolution, a Comparison between Java and the Netherlands at the Beginning of the $19^{\text {th }}$ Century." Explorations in Economic History 40 (2003) 1-23.

Yamazawa, Ippei and Yamamoto, Yuzo (1979) LTES, Vol. 14, Foreign Trade and Balance of Payments. Tokyo: Toyo Keizai Shinposha.

Yamamoto, Yuzou (2000), Nihon Shokuminchi Keizai Shi Kenkyuu (Studies on the Economic History of Japanese Colonies), Nagoya: Nagoya University Publishing House. 2000.

(1989) "Japanese Empire and Colonial Management" in Takafusa Nakamura and Konosuke Odaka eds., Nihon Keizai Shi (Economic History of Japan), Vol. 6, Dual Structure. Tokyo: Iwanami Shoten. 
Table 1. Aggregate Rural and Urban Expenditure Weights in 1934-36

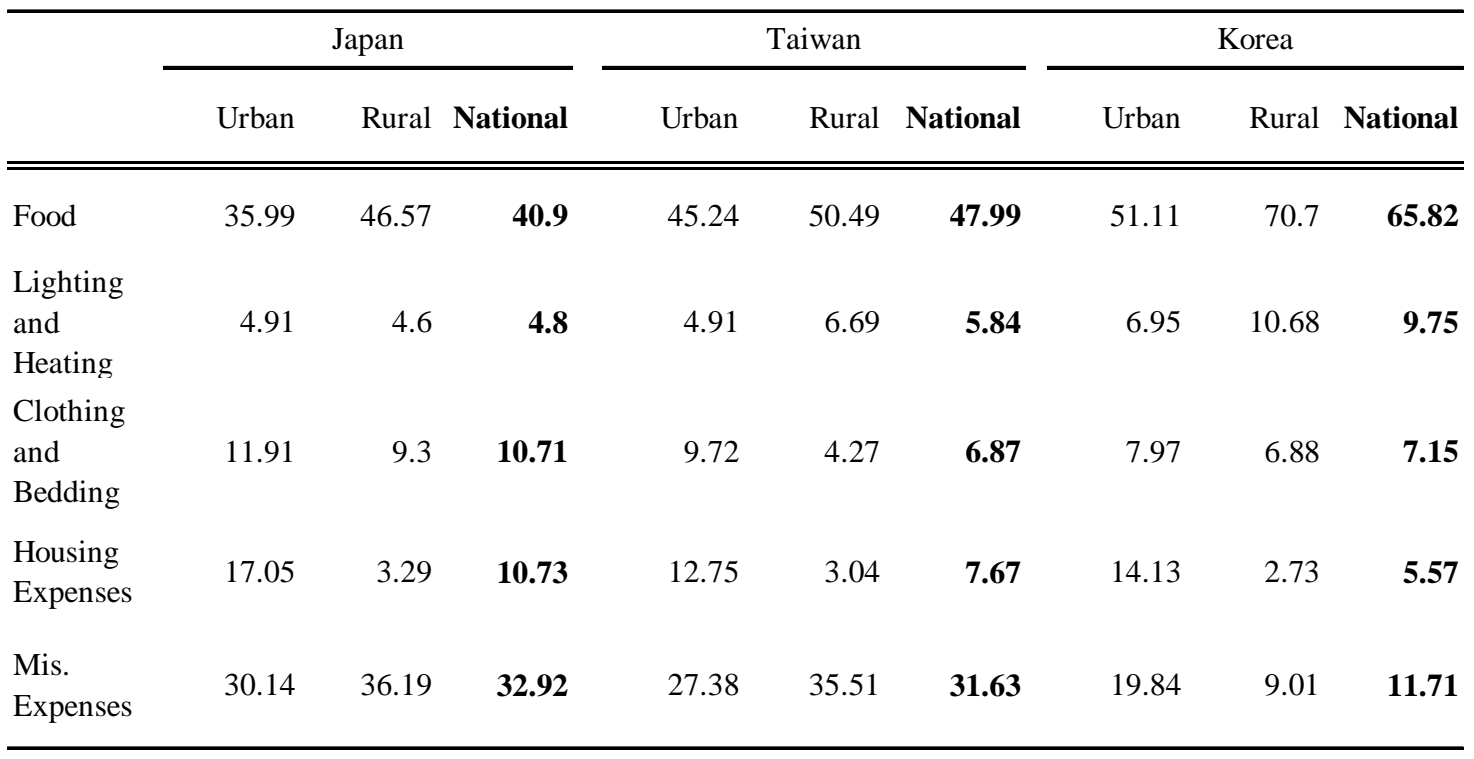

Source Notes: The urban expenditure weights for Taiwan and Korea are from Mizoguchi, "Worksheet No. 9," The rural weights from Mizoguchi (1975, p.10). For Japanese weights and data source, see the explanation in Appendix 1. The rural share of population in Taiwan and Korea are 52 and 75 per cent respectively, calculated from M\&U volume, pp. 235, 237, 263 and 268. 
Table 2. Relative Price Levels by Sectors (1934-36 Japan =1)

\begin{tabular}{lcc}
\hline \multicolumn{1}{c}{ Sectors } & Korea & Taiwan \\
\hline \hline Total & $\mathbf{0 . 8 6}$ & $\mathbf{0 . 8 4}$ \\
Tradables: & 0.93 & 0.88 \\
$\quad$ Food & 0.94 & 0.87 \\
Other Tradables & 0.91 & 0.89 \\
Non-tradable: & 0.71 & 0.78 \\
\hline
\end{tabular}

Notes:

1. Tradable goods for Korea: food, coal, firewood, charcoal, oil, cotton, bleached cloth, underwear, socks, shoes, umbrellas, Western umbrellas, cement, kneaded tiles, tea bowls, soap, health pills, writing paper.

Tradable goods for Taiwan: food, firewood, charcoal, coke, cotton, muslin, cotton flannel, cement, tatami mats, kneaded tiles, cedarboard, soap, writing paper, Minogami paper.

2. Relative price levels in the above three categories are calculated using the Fisher formule. For Japan-Taiwan comparison, Japanese and Taiwanese weights used for the categories of food, other tradables and non-tradables are 41, 19, 40 and 48, 19, 37 percent respectively. For Japan-Korea comparison, Japanese and Korean weights used for the same three categories are 41, 21, 38 and $66,17,17$ percent respectively. 
Table 3. Real Per-capita GDP (GDE) of Korea and Taiwan Relative to Japan (Japan =1)

\begin{tabular}{cccccc}
\hline & \multicolumn{2}{c}{ PPP Adjusted Estimate } & & \multicolumn{2}{c}{ Exchange Rate Converted Estimate } \\
\cline { 2 - 3 } \cline { 5 - 6 } & Korea & Taiwan & & Korea & Taiwan \\
\hline \hline 1915 & 0.52 & 0.78 & & 0.37 & 0.62 \\
1920 & 0.46 & 0.74 & & 0.38 & 0.64 \\
1925 & 0.45 & 0.78 & & 0.34 & 0.54 \\
1930 & 0.44 & 0.83 & & 0.31 & 0.61 \\
1935 & 0.44 & 0.79 & & 0.38 & 0.66 \\
\hline
\end{tabular}

Sources : Data for Japan are from Ohkawa and Shinohara (1979), Korea and Taiwan from Mizoguchi and Nojima (1996). For years before 1935, the PPP adjusted real GDP per capita estimates are obtained by extrapolating backward our 1934-36 benchmark PPP estimate. 
Table 4 Per Capita GDP and Comparative Price Levels

\begin{tabular}{|c|c|c|c|c|c|c|c|c|c|c|}
\hline & \multicolumn{6}{|c|}{ Per Capita GDP (GDE) } & \multirow{2}{*}{\multicolumn{2}{|c|}{$C P L_{i, J}^{E}(t, 90)$}} & \multirow{2}{*}{\multicolumn{2}{|c|}{$\begin{array}{c}\text { Maddison Per Capit } \\
\text { GDP estimate } \\
(\text { Japan }=1)\end{array}$}} \\
\hline & \multicolumn{2}{|c|}{ Japan } & \multicolumn{2}{|c|}{ Korea } & \multicolumn{2}{|c|}{ Taiwan } & & & & \\
\hline & LTES & Maddison & $M \& U$ & Maddison & $M \& U$ & Maddison & $\begin{array}{l}\text { Korea/Japan } \\
=(3 / 4) /(1 / 2)\end{array}$ & $\begin{array}{c}\text { Taiwan/Japan } \\
=(5 / 6) /(1 / 2)\end{array}$ & Korea & Taiwan \\
\hline Cols. & $\overline{1}$ & 2 & $\overline{3}$ & $\overline{4}$ & $\overline{5}$ & $\overline{6}$ & 7 & 8 & $\overline{9}$ & 10 \\
\hline 1915 & 96.29 & 1375 & 35.51 & 1116 & 59.47 & 804 & 0.45 & 1.06 & 0.81 & 0.58 \\
\hline 1920 & 276.26 & 1631 & 103.97 & 1167 & 175.69 & 921 & 0.53 & 1.13 & 0.72 & 0.56 \\
\hline 1925 & 288.67 & 1814 & 96.85 & 1175 & 156.37 & 1041 & 0.52 & 0.94 & 0.65 & 0.57 \\
\hline 1930 & 226.39 & 1780 & 69.39 & 1173 & 138.57 & 1112 & 0.47 & 0.98 & 0.66 & 0.62 \\
\hline 1935 & 248.78 & 2040 & 94.23 & 1420 & 163.71 & 1291 & 0.54 & 1.04 & 0.7 & 0.63 \\
\hline
\end{tabular}

Sources: the nominal GDP series are in yen; Japan, the LTES series from Ohkawa and Shinohara (1979), The M\&U series for Korea and Taiwan are from M\&U (1988). The Maddison series are real GDP figures in 1990 Geary-Khamis dollars from Maddison (1995). Maddison's series are largely based on M\&U nominal series with per-capita GDP computed from the Maddison population data. 
Table 5. Per Capital Income and Expenditure in Urban Households in 1937 yen (unadjusted for Purchasing Power Parity)

\begin{tabular}{|c|c|c|c|c|c|c|}
\hline & \multirow{2}{*}{\multicolumn{2}{|c|}{ Japan }} & \multicolumn{4}{|c|}{ Taiwan } \\
\hline & & & \multicolumn{2}{|c|}{ Japanese Residents } & \multicolumn{2}{|c|}{ Taiwanese } \\
\hline & Income & Expenditure & Income & Expenditure & Income & Expenditure \\
\hline Total & 287 & 246 & 333 & 289 & 172 & 157 \\
\hline Salaried worker & 319 & 276 & 408 & 350 & 223 & 184 \\
\hline Laborer & 270 & 229 & 292 & 256 & 145 & 143 \\
\hline
\end{tabular}

Sources: Japan is from Kakei Chousa (1937, Sept. and 1938, August) compiled by the Statistical Bureau of the Japanese Interior Ministry. Taiwan is from Kakei Chousa Houkoku, Nov. 1937 and Oct. 1938. There are 1601 families surveyed in Japan, 390 Taiwanese families and 355 Japanese residents' families surveyed in Taiwan. For details, also see Appendix A.

Notes: The salaried workers include teachers, bankers and civil servants while the laborers include industrial and transportation workers. For all three categories, I have consistently applied the Japanese occupational weights in the Japan sample. 
Figure 1-a Real Per Capita GDP based on our Consumption PPP(in 1934-36Japanese yen)

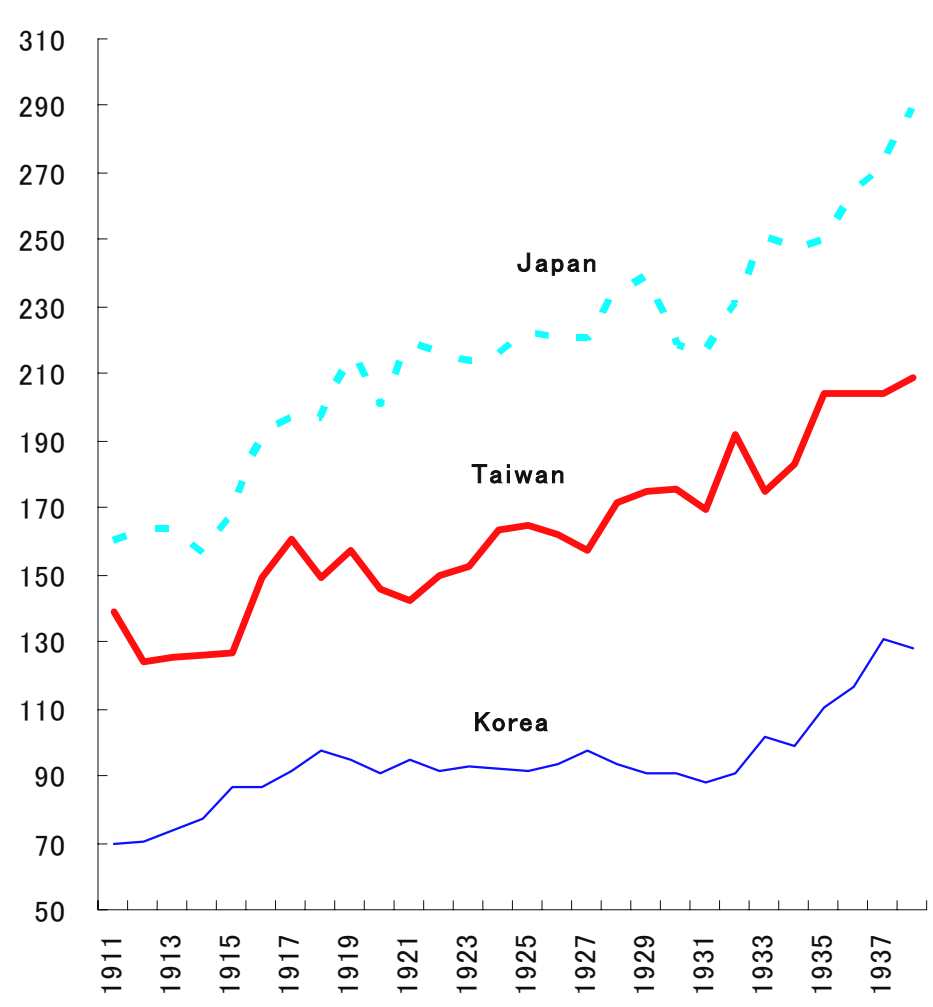

Figure 1-b Maddison's real percapitaGDP (1990Geary-Khamis Dollars)

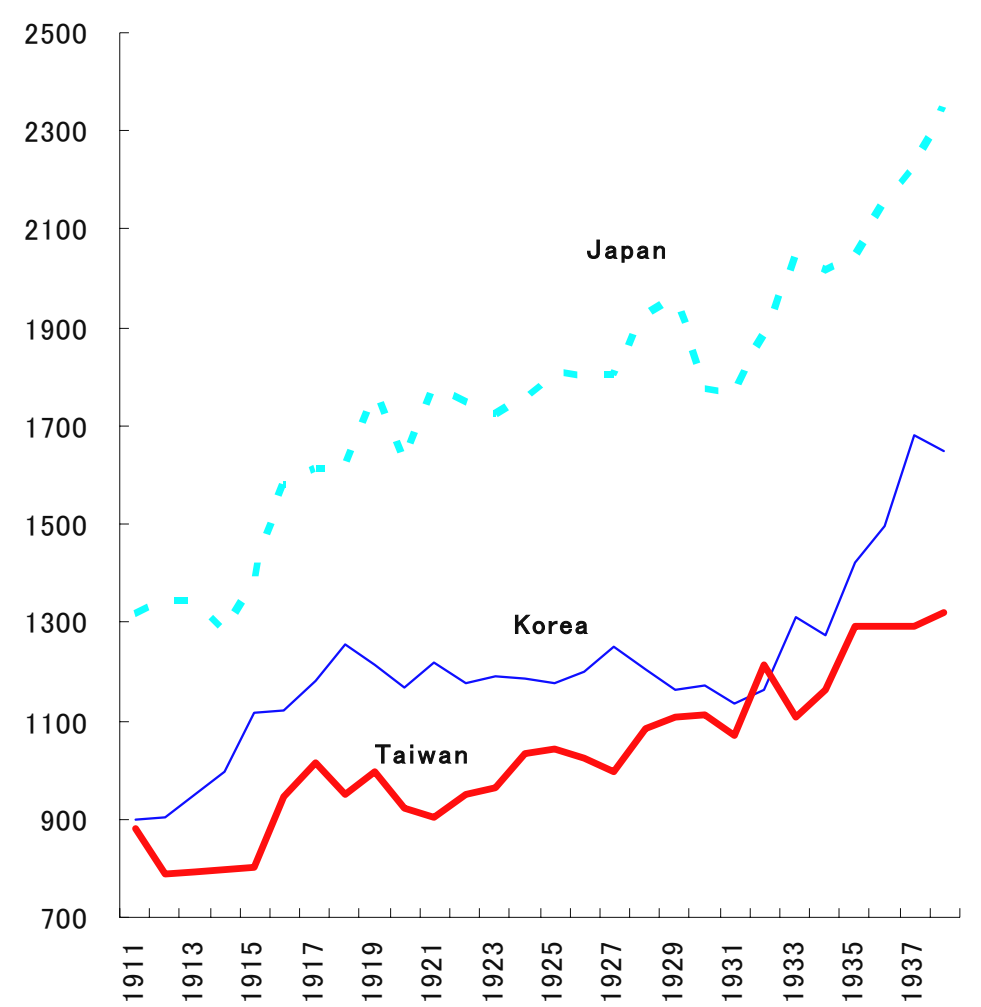

Note: See the text. 
Figure 2. Ratio of Benchmark CPLs to Extrapolated CPLs (1990=1)

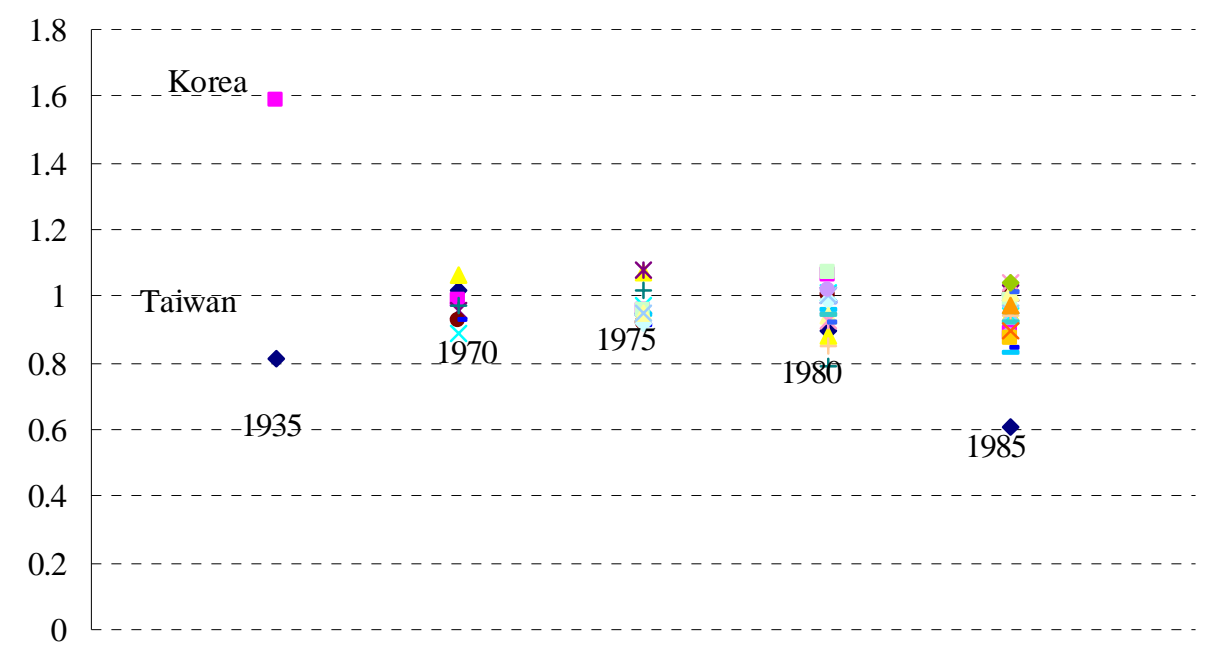

Sources: see the text 
Figure 3. Sectoral GDP Shares and Relative Per Capita GDP (US=1) of Japan,

Taiwan and Korea in 1935 and 1990

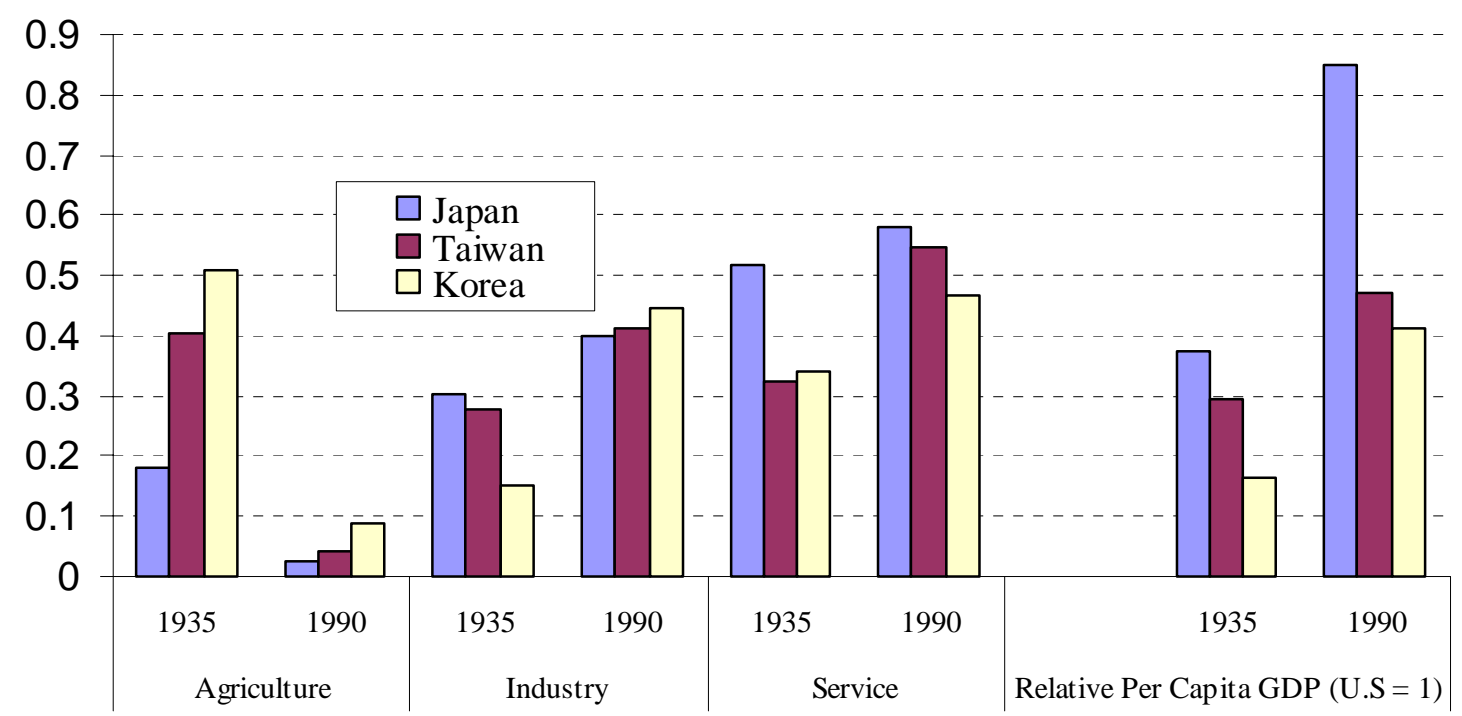

Sources: 1935 sectoral shares data from M\&U, Tables 3, 5 and 7. 1990 sectoral shares data for Japan and Korea are from Dirk Pilat, 1994, p. 279 and 297. The 1935 PPP per capita data is based on this paper. To link with the U.S, we used data from Maddison, 1995. Korea for 1990 is for South Korea only. 


\section{Appendix A: Data Source}

Price Data:

Japan: Among the three countries, price data on Japan are the best and used as a benchmark for comparison. We relied mostly on the relevant issues of Nihon Teikoku Toukei Nenkan (Statistical Annals of the Japanese Empire) and Bukka Toukei Hyou (Statistical Tables of Prices) by Shoukou Daijin Kanbou Toukeika (Government Statistics Department of the Ministry of Commerce and Industry). In addition, we also used the relevant issues of Tokyo Bukka Oyobi Chingin Toukei (Tokyo Price and Wage Statistics) by Tokyo Shoukou Kaigisho (Tokyo Council of Commerce and Industry), Senzen Kijun Shouhi Suijun---Tokyo Sanshutu Houhou (1), Toukei Shiryou Dai 78 Go (Pre-War Standard Consumption Level - Method of Calculation for Tokyo (1), Statistical Materials No. 78) by Keizai Shingichou Chousabu Toukeika (Statistical Survey Department of the Economic Council) (1953), and Shouwa 11 Nendo Tokyo Shi Toshi Koutuu Toukei Shiryou Dai 2 Kai (1936 Tokyo Metropolitan Transportation Statistics No.2) by Tokyo Shi Denki Kyoku (Tokyo Electricity Bureau), (1936).

Korea: We used various issues of the Statistical Annals of the Korea Government-General published by Chousen Soutokufu. The number of available product prices in 1935 was smaller than after 1936. To match with products for Japan, we often have to use individual year prices instead of the three-year averages. Chousen Shouhin Torihiki Binran (A Guide for Korean Products) issued by Chousen Soutokufu Shoukou Shoureikan (1937) contained rich price information for 1936. We also acquired some price data from newspapers, Chousen Nippou, and Chииои Nippou.

Taiwan: Available retail prices are not as plentiful. In various cases, we used wholesale prices to match with wholesale prices in Japan and Korea. The price data are mostly from relevant issues of Taiwan Soutokufu Toukei Shou (Statistics of the Taiwan Government-General) published by Taiwan Shoutoku Kanbou Chousabu (later renamed as Keikakubu) and Taiwan Shoukou Toukei (Statistics of Taiwan Commerce and Industry) published by Taiwan Soutokufu Shokusankyoku, and Taiwan Sheng 51 Nian Tongji Tiyao (51 Years of Statistical Summary of Taiwan Province) compiled by the new Chinese Komingdang government in 1946 (Taiwan Sheng Xingzeng Zhangguan Kongsu). Classification of commodities among these publications is also roughly comparable. For service sectors such as expenses for housing, medical care, education, 
transportation and entertainment, we gathered prices from Denki Tuushin Youran (A Summary of Electrical, Transportation and Communication Utilities) by Taiwan Soutokufu Koutuukyoku (various yearly issues), Taiwan Shakai Jigyou Youran (A Summary Guide to Taiwan Social Facilities), Nichinichi Shinbun (Everyday News) published by Taiwan Soutokufu Bunkyoukyoku (1935). We also used the following materials from The Series on Chinese Local Gazette, No. 160 of "Taiwan Annai," No.183 of "Rakuen Taiwan no Sugata," and No.190 of "Yakushin Taiwan Taikan.” This Local Gazette Series was originally published before the War, reprinted in 1985 by Taipei Cengwen Publishing Ltd.

\section{Expenditure Weights:}

Consumption expenditure weights vary by levels of aggregation according to the source of data. We use three levels of weights, the upper (the most aggregated 5 levels), the medium and the lower level. These weights are based on a combination of household budget surveys conducted for cities and rural areas.

Japan: the Japanese upper level weights are the weighted averages of expenditure shares derived from the relevant yearly series of the urban based Household Expenditure Survey (Kakei Chousa) published by the Statistical Bureau of the Japanese Interior Ministry, and the rural based Agricultural Household Economic Survey (Nouka Keizai Chousa) published by the Economic Recovery Department of the Ministry of Agriculture and Forestry. The weights are assigned according to the actual shares of urban and rural households within Japan. The same methodology applies to both Korea and Taiwan. For the lower level weights we use the result of vol.6, Private Consumption Expenditure of LTES. To match with Korea and Taiwan, we constructed the medium level weight from the 113 products used in this volume.

For weights on Taiwan and Korea, we largely follow Mizoguchi (1971):

Korea: As there is no urban household budget survey, we constructed the urban expenditure weights using the The 1961 Household Expenditure Survey Report, conducted by the Economic Planning Council of the Republic of Korea in 1962. There are three farm household budget surveys conducted in 1930, 1932-33, and 1937-39. The 1930 survey, [Report on Farm Household Economy], conducted by the Korean Agricultural Association and published in 1932-3, includes several separate volumes for different regions. The two other surveys are the 1932-33 and 193739 Nouka Keizai Gaikyou Chousa (Surveys on Economic Conditions of Agricultural Households for Self, part-self-and-part-tenancy and Tenancy cultivators) published in 1940 by the 
Agricultural Recovery Department of the Ministry of Agriculture and Forestry of the Korean Governor-General (Chousen Soutokufu Nourinkyoku Nourin Shinkouka). Although the sample size of the 1937 - 39 survey was fairly large, detailed information on consumption weights were missing. Mizoguchi (1971) opted for the 1930 survey.

Taiwan: The Economic Planning Committee of the Taiwan Governor General (Taiwan Soutokufu Kanbou Kikakubu) conducted surveys for urban working households in Nov. 1937 and Oct. 1938, which were published as Kakei Chousa Houkoku (Household Expenditure Survey) in 1940. This survey, which sampled 355 families of Japanese migrants and 390 Taiwanese families in urban Taiwan could certainly be considered as fairly large scale by the standard of the time. Unfortunately, there are only expenditure weights at the medium level. For lower level weights, we relied on the 1954-55 urban household budget survey in Zhonghua Minguo Taiwan Shenn Xinci Jieji Jiaji Tiaoca published by the Statistics Department of the Taiwan Provincial Government in 1955.

For rural areas, there were two agricultural household surveys in 1918-21 and 1931-33. For the five category upper level weights, we used the 1931-33 survey Taiwan Nouka Keizai Chousa Houkoku, No. 1 and 2, also listed as No. 30 and 32 of Nougyou Kihon Chousasho, released by Taiwan Soutokufu Shokusankyoku in 1933. For the medium and lower weights, we follow Mizoguchi to apply the result obtained from the urban surveys. 
A-1 Korean Price Level Relative to Japan (1934-36 : Japan=1)

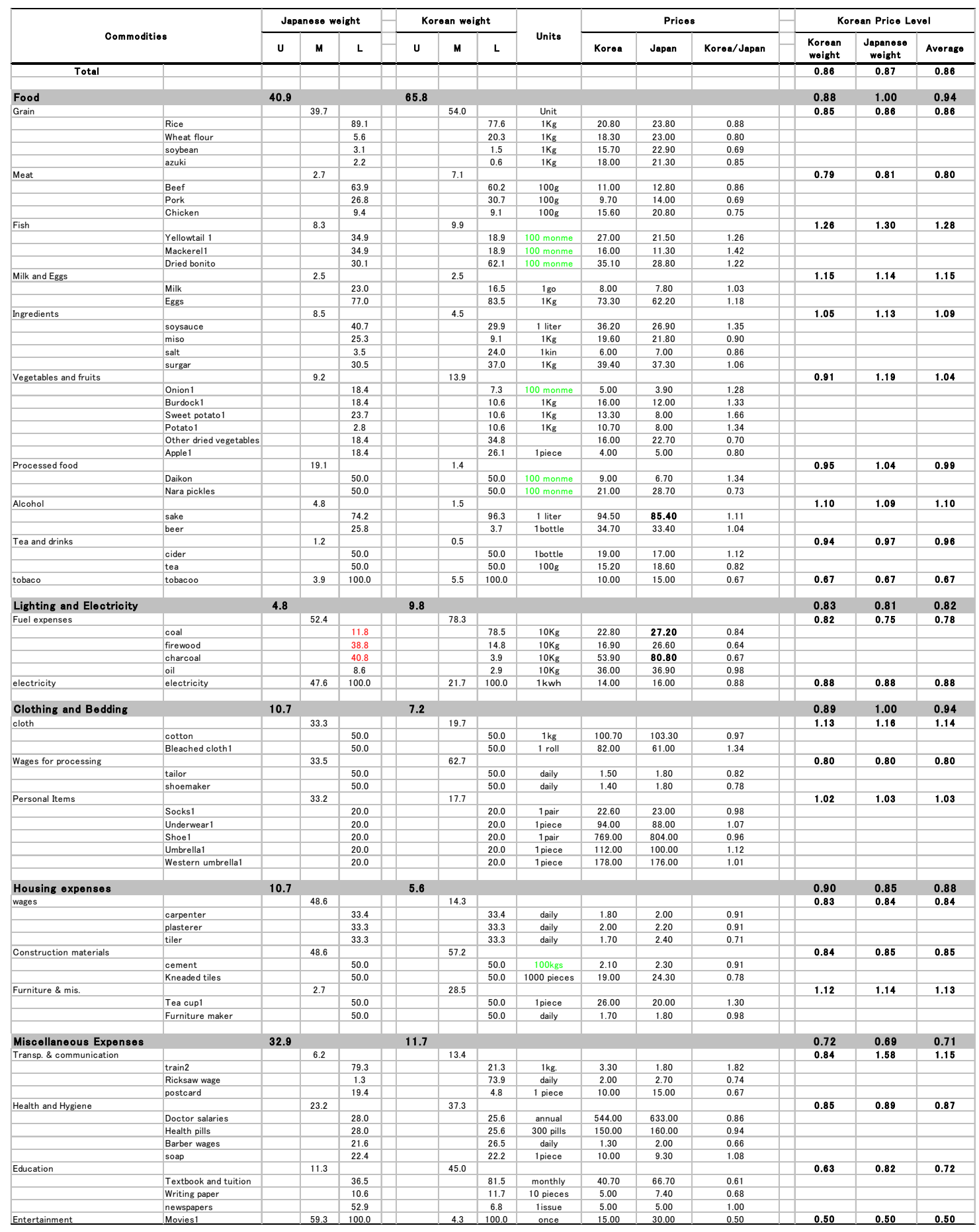

Source: see the explanation in the Appendix. Notes: items marked with 1 are the regional average of consumer prices in 1936. Items marked with 2 are the average of Tokyo and Seoul in 1936. All other prices are the 1934-36 regional averages of consumer prices. 
A-2 Taiwanese Price Level Relative to Japan (1934-36 : Japan=1)

\begin{tabular}{|c|c|c|c|c|c|c|c|c|c|}
\hline & & & rese $\mathrm{w}$ & & & anese w & reight & & \\
\hline Commoditios & & & & & & & & Unit & \\
\hline$\overline{\text { Total }}$ & & & & & & & & & \\
\hline & & & & & & & & & \\
\hline Food & & 40.9 & & & 48.0 & & & & \\
\hline Grain & & & 33.2 & & & 39.0 & & & \\
\hline & Rice & & & 93.3 & & & 96.7 & $1 \mathrm{Kg}$ & 21.20 \\
\hline & Wheat flour & & & 6.7 & & & 3.3 & $1 \mathrm{Kg}$ & 25.50 \\
\hline Fish & & & 8.3 & & & 11.9 & & & \\
\hline & Mackerel 3 & & & 33.3 & & & 33.3 & $100 \mathrm{~kg}$ & 11.30 \\
\hline & Tuna 3 & & & 33.3 & & & 33.3 & $100 \mathrm{~kg}$ & 31.00 \\
\hline & Dried bonito & & & 33.4 & & & 33.4 & $100 \mathrm{~g}$ & 26.45 \\
\hline Meat & & & 2.7 & & & 17.0 & & & \\
\hline & Pork & & & 26.8 & & & 79.3 & $100 \mathrm{~g}$ & 7.61 \\
\hline & Beef & & & 63.9 & & & 4.2 & $100 \mathrm{~g}$ & 9.24 \\
\hline & Chicken & & & 9.4 & & & 16.5 & $100 \mathrm{~g}$ & 20.93 \\
\hline Eggs & & & 2.0 & & & 2.8 & & & \\
\hline & Chicken eggs & & & 82.9 & & & 82.9 & $1 \mathrm{Kg}$ & 75.70 \\
\hline & Duck eggs & & & 17.1 & & & 17.1 & $1 \mathrm{~kg}$ & 59.40 \\
\hline Milk & & & 0.6 & & & 0.7 & & & \\
\hline & Milk & & & 100.0 & & & 100.0 & 16ottle & 9.90 \\
\hline Vegetables and soybeans & & & 11.0 & & & 9.7 & & & \\
\hline & Soybeans & & & 11.2 & & & 23.9 & $1 \mathrm{Kg}$ & 21.13 \\
\hline & Potato & & & 2.3 & & & 4.4 & $1 \mathrm{Kg}$ & 14.31 \\
\hline & Radish 4 & & & 22.1 & & & 23.9 & $100 \mathrm{Kg}$ (yen) & 2.30 \\
\hline & Burdock 4 & & & 22.1 & & & 23.9 & $100 \mathrm{~kg}$ (yen) & 3.80 \\
\hline & Onion4 & & & 22.1 & & & 23.9 & $100 \mathrm{~kg}$ (yen) & 6.00 \\
\hline & Sweet potato & & & 19.9 & & & 13.0 & $1 \mathrm{Kg}$ & 5.10 \\
\hline Ingredients & & & 8.5 & & & 8.8 & & & \\
\hline & Sugar & & & 12.2 & & & 14.5 & $1 \mathrm{Kg}$ & 36.90 \\
\hline & Miso & & & 18.8 & & & 11.5 & $1 \mathrm{Kg}$ & 16.27 \\
\hline & Soysauce & & & 28.7 & & & 33.7 & 1 liter & 36.30 \\
\hline & Peanut Oil & & & 40.4 & & & 40.4 & $1 \mathrm{Kg}$ & 44.72 \\
\hline Processed food & & & 23.8 & & & 6.1 & & & \\
\hline 年 & Dried salty fish & & & 33.3 & & & 33.3 & $1 \mathrm{Kg}$ & 27.06 \\
\hline & dried squid & & & 33.3 & & & 33.3 & $1 \mathrm{Kg}$ & 95.30 \\
\hline & Daikon & & & 33.4 & & & 33.4 & $100 \mathrm{momme}$ & 9.10 \\
\hline Drinks & & & 1.2 & & & 0.9 & & & \\
\hline & Tea & & & 100.0 & & & 100.0 & $100 \mathrm{~g}$ & 18.15 \\
\hline Alcohol & & & 8.7 & & & 3.2 & & & \\
\hline & Sake & & & 74.2 & & & 77.7 & 1liter & 189.00 \\
\hline & Beer & & & 25.8 & & & 22.3 & $\begin{array}{l}\text { 16ottle } \\
(633 \mathrm{cc})\end{array}$ & 33.00 \\
\hline Lighting and Heating & & 4.8 & & & 5.8 & & +5 & & \\
\hline Electricity & & & 47.6 & & & 24.7 & & & \\
\hline & Electricity & & & 100.0 & & & 100.0 & $1 \mathrm{KWH}$ & 15.00 \\
\hline Fuel & & & 52.4 & & & 75.3 & & & \\
\hline & Firewood & & & 42.5 & & & 20.9 & $10 \mathrm{~kg}$ & 42.04 \\
\hline & Charcoal & & & 44.6 & & & 44.3 & $10 \mathrm{~kg}$ & 23.43 \\
\hline & coke & & & 12.9 & & & 34.8 & $10 \mathrm{~kg}$ & 25.30 \\
\hline Clothing and Bedding & & 10.7 & & & 6.9 & & - & 2 & \\
\hline Clothing & & & 66.5 & & & 56.9 & & & \\
\hline & Cotton & & & 33.4 & & & 33.4 & $1 \tan$ & 83.00 \\
\hline & Muslin & & & 33.3 & & & 33.3 & $1 \mathrm{~m}$ & 61.60 \\
\hline & Cotton flannel & & & 33.3 & & & 33.3 & $1 \mathrm{~m}$ & 27.80 \\
\hline Wages & & & 33.5 & & & 43.1 & & & \\
\hline & $\begin{array}{l}\text { Tailors } \\
\text { stive) }\end{array}$ & & & 333 & & & 333 & daily & \\
\hline & $\begin{array}{l}\text { style) } \\
\text { Shoemaker }\end{array}$ & & & $\begin{array}{l}33.3 \\
33.3\end{array}$ & & & $\begin{array}{l}33.3 \\
33.3\end{array}$ & dally & 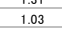 \\
\hline & $\begin{array}{l}\begin{array}{l}\text { Tailors } \\
\text { sty) }\end{array} \\
\text { (Taivanese }\end{array}$ & & & 33.4 & & & 33.4 & daily & 1.00 \\
\hline Housing Expenses & & 10.7 & & & 7.7 & & & & \\
\hline Construction wages & & & 48.6 & & & 28.6 & & & \\
\hline & Carpenter & & & 33.3 & & & 33.3 & daily & 1.78 \\
\hline & Bricklayer & & & 33.4 & & & 33.4 & daily & 1.72 \\
\hline & Plasterer & & & 33.3 & & & 33.3 & daily & 1.72 \\
\hline Construction Materials & & & 48.6 & & & 58.1 & & & \\
\hline & Cement 3 & & & 13.5 & & & 13.5 & Itaru (yen) & 4.80 \\
\hline & Tatami mats3 & & & 13.5 & & & 13.5 & 10 pieces & 732.00 \\
\hline & Kneaded bricks 3 & & & 13.5 & & & 13.5 & 1000 pieces & 15.16 \\
\hline & Cedarboard 3 & & & 59.7 & & & 59.7 & Itsubo & 1.40 \\
\hline Mis. & & & 2.7 & & & 13.3 & & & 1.80 \\
\hline & $\begin{array}{l}\text { Wage of furniture } \\
\text { maker }\end{array}$ & & & 100.0 & & & 100.0 & & 1.39 \\
\hline Mis. Expenses & & 329 & & & 31.6 & & & & \\
\hline Transportation and Communication & & & 6.2 & & & 12.7 & & & \\
\hline & Car 2 & & & 39.7 & & & 23.9 & $1 \mathrm{~km}$ & 1.33 \\
\hline & Rail staff & & & 397 & & & 23.9 & $\begin{array}{l}\text { Monthly } \\
\text { (vent }\end{array}$ & 4302 \\
\hline & Ricksaw wage & & & 1.3 & & & 47.7 & \begin{tabular}{|l|l} 
Daily (yen) \\
\end{tabular} & 1.01 \\
\hline & Postcard & & & 194 & & & 46 & 1pice & 150 \\
\hline Health and Hygiene & & & 23.2 & & & 47.9 & & & \\
\hline & Soap & & & 22.4 & & & 19.0 & 1piece & 10.00 \\
\hline & Public bath & & & 10.8 & & & 9.5 & 1 time & 3.00 \\
\hline & Wage of barber & & & 10.8 & & & 9.5 & Daily (yen) & 0.93 \\
\hline & Salary of doctors & & & 56.0 & & & 62.0 & Annual & 536.70 \\
\hline Stationeries & & & 0.6 & & & 4.0 & & & \\
\hline & Writing paper & & & 500 & & & 500 & $\begin{array}{l}20 \text { pieces } \\
\text { (1)uire) }\end{array}$ & 743 \\
\hline & T. & & & 50. & & & -50 & 50pieces & a \\
\hline Education & Minogami paper & & 10.7 & 50.0 & & 19.7 & 50.0 & & 41.27 \\
\hline & Teacher salary & & & 100.0 & & & 100.0 & monthly & 53.54 \\
\hline Education & & & 59.3 & & & 15.7 & & & \\
\hline & Newspapers & & & 50.0 & & & 50.0 & 1 issue & 5.00 \\
\hline & Magazines & & & 50.0 & & & 50.0 & lissue & 40.00 \\
\hline
\end{tabular}

Notes: "2" is the consumer price for Tokyo and Taipei, "3" is the regional average retail price for 1934-36, "4"is the retail price of Tokyo and Taipei. All others are regional average consumer prices. 


\section{A-3 Korean Price Level Relative to Taiwan (1934-36 : Japan=1)}

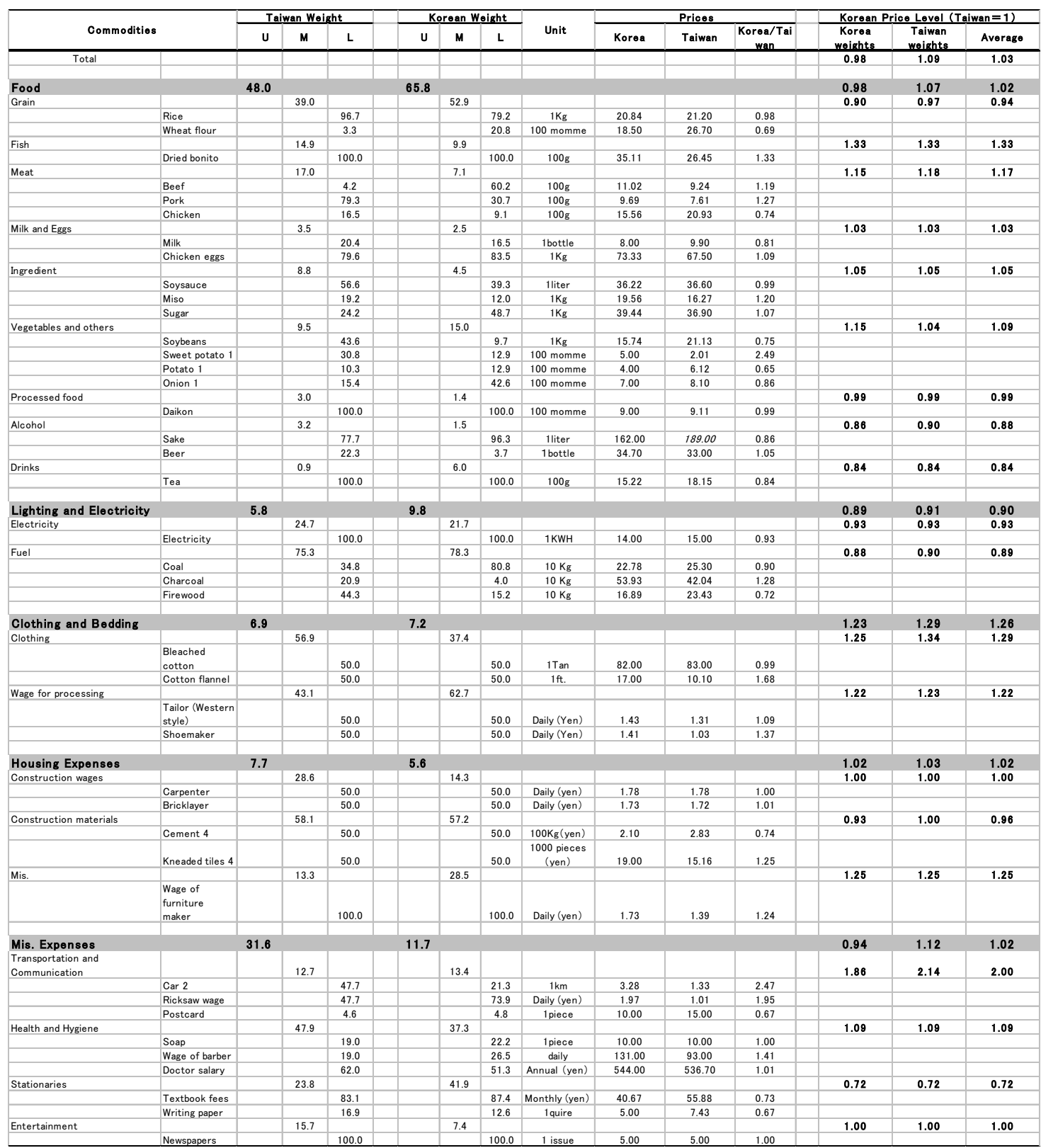

Notes: see notes to Appendix A-1 and A-2. 


\section{Appendix B. How Terms of Trade Affect Extrapolation Biases: an Empirical Test}

In equation (1) in the text, we have decomposed the gap between backward projected benchmark CPL and the current price benchmark CPL into two components: the terms of trade effect and the Gerschenkron effect. In this Appendix, we would like to empirically test this hypothesis using the data in Heston and Summers (1993) which gave CPL ratios of 23 OECD countries for every five years in the period of 1970-90 based on 1990 as the benchmark year for backward projection.

Gerschenkron effects are only significant for countries experiencing substantial structural change. Since OECD countries in 1970-90 were already quite developed and relatively homogenous, our statistical test will focus on the terms of trade effect, treating the Gerschenkron effects as random errors.

Table 3 of Heston and Summers (1993) reports

$$
\frac{Z_{i}(t, 90)}{Z_{E U}(t, 90)}=\frac{C P L^{C}{ }_{i, E U}(t)}{C P L_{i, E U}^{E}(t, 90)}
$$

where the variables with EU denote values of EU core countries (UK, West Germany and Italy). By taking a first difference of equation (1) over time and treating Gerschenkron effects as a component of error term, we derive the following:

$$
\begin{aligned}
\ln & \left(\frac{Z_{i}(t+1,90)}{Z_{E U}(t+1,90)}\right)-\ln \left(\frac{Z_{i}(t, 90)}{Z_{E U}(t, 90)}\right) \\
& =\left\{\ln \left(\frac{\sum p_{n}^{G}(t+1) e_{n}^{i}(t)}{\sum p_{n}^{G}(t) e_{n}^{i}(t)}\right)-\ln \left(\frac{\sum p_{n}^{G}(t+1) e_{n}^{E U}(t)}{\sum p_{n}^{G}(t) e_{n}^{E U}(t)}\right)\right\} \\
& +\left\{\ln \left(\frac{\sum p_{n}^{G}(t+1) e_{n}^{i}(90)}{\sum p_{n}^{G}(t+1) e_{n}^{i}(t+1)}\right)-\ln \left(\frac{\sum p_{n}(t+1) e_{n}^{i}(90)}{\sum p_{n}(t+1) e_{n}^{i}(t+1)}\right)\right\} \\
& -\left\{\ln \left(\frac{\sum p_{n}^{G}(t+1) e_{n}^{i}(90)}{\sum p_{n}^{G}(t+1) e_{n}^{i}(t)}\right)-\ln \left(\frac{\sum p_{n}(t) e_{n}^{i}(90)}{\sum p_{n}(t) e_{n}^{i}(t)}\right)\right\} \\
& +\left\{\ln \left(\frac{\sum p_{n}^{G}(t+1) e_{n}^{E U}(90)}{\sum p_{n}^{G}(t+1) e_{n}^{E U}(t+1)}\right)-\ln \left(\frac{\sum p_{n}(t+1) e_{n}^{E U}(90)}{\sum p_{n}(t+1) e_{n}^{E U}(t+1)}\right)\right\} \\
& -\left\{\ln \left(\frac{\sum p_{n}^{G}(t+1) e_{n}^{E U}(90)}{\sum p_{n}^{G}(t+1) e_{n}^{E U}(t)}\right)-\ln \left(\frac{\sum p_{n}(t) e_{n}^{E U}(90)}{\sum p_{n}(t) e_{n}^{E U}(t)}\right)\right\}
\end{aligned}
$$

Here, $t$ is equal to $1970,75,80$, and 85 . The first term in the right-hand side of the equation denotes the terms of trade effect. The rest of the terms on the right-hand side denote 
Gerschenkron effects, which is treated as an error term.

Let $d_{n}^{i}(t)$ and $x_{n}^{i}(t)$ denote domestic demand and net exports of commodity $n$ in country $i$ in year $t$. Commodity balance ensures the equality, $e_{n}^{i}(t)=d_{n}^{i}(t)+x_{n}^{i}(t)$. To simplify our analysis we set the following additional assumptions.

i) Each country's balance of trade and services is close to zero.

ii) Each country has a similar demand structure.

iii) The GK price vector is close to the international price, to which each country faces.

Then, the first term on the right-hand side of equation (A2) can be approximated by

$$
\ln \left(\frac{\sum\left\{p_{n}^{G}(t+1)-p_{n}^{G}(t)\right\} x_{n}^{i}(t)}{\sum p_{n}^{G}(t) e_{n}^{i}(t)}\right)-\ln \left(\frac{\sum\left\{p_{n}^{G}(t+1)-p_{n}^{G}(t)\right\} x_{n}^{E U}(t)}{\sum p_{n}^{G}(t) e_{n}^{E U}(t)}\right)
$$

and given our assumptions, could be further simplified as follows:

$$
m^{i}(t)\left\{\ln \left(T^{i}(t+1)\right)-\ln \left(T^{i}(t)\right)\right\}-m^{E U}(t)\left\{\ln \left(T^{E U}(t+1)\right)-\ln \left(T^{E U}(t)\right)\right\}
$$

where $m^{i}(t)$ denotes the simple average of country $i$ 's export-GDP ratio and import-GDP ratio. We also call $m$ as the trade dependence ratio. $T^{i}(t)$ denotes country $i$ 's terms of trade in time $t$. As the terms of trade effect of the core EU countries will affect all countries' PPP gap in the same way, we use time dummies to control for it.

From the above analysis we get the following model for our econometric test.

$$
\begin{aligned}
& \ln \left(\frac{Z_{i}(t+1,90)}{Z_{E U}(t+1,90)}\right)-\ln \left(\frac{Z_{i}(t, 90)}{Z_{E U}(t, 90)}\right) \\
& \quad=\alpha+\beta m^{i}(t)\left\{\ln \left(T^{i}(t+1)\right)-\ln \left(T^{i}(t)\right)\right\}+\sum_{\tau} \gamma_{\tau} D U M_{\tau}(t)+\varepsilon^{i}(t)
\end{aligned}
$$

where $D U M_{\tau}(t)$ is the time dummy.

Regression using the above equation with data in Heston and Summers (1993) is tabulated as follows. Notice that $D 8085$ and $D 8590$ are time dummies. $\beta$, the coefficient of the cross term of change of terms of trade and trade dependence ratio is the key variable. From our theory, we expect $\beta$ to be close to -1 . When a country's terms of trade deteriorate, extrapolation bias will increase. This effect will be larger for countries with higher trade dependence. From the regression table, our $\beta$ coefficient is close to -1 and statistically significant, thus confirming our theory.

\begin{tabular}{cccc}
\hline & Coefficients & Standard error & $t$ \\
\hline \hline$\alpha$ & -0.0147 & 0.019 & -0.763 \\
$\beta$ & -0.651 & 0.156 & -4.167 \\
$D 8085$ & $3.46 \mathrm{E}-05$ & 0.025 & 0.001 \\
$D 8590$ & 0.0943 & 0.025 & 3.751 \\
\hline
\end{tabular}

$R$ square $=0.49$ 